\title{
Reforms Feasibility in Kurdistan Region Petroleum Contracts, Triggered by the New Regional Blocks Divisions
}

\author{
Rdhwan Shareef Salih \\ Lecturer \\ Department of Law \\ Faculty of Law, Political Science and Management \\ Soran University \\ Kurdistan Region - Iraq \\ Dr. Akram Yamulki \\ Department of Law \\ Faculty of Law and International Relations \\ Cihan University - Erbil \\ Kurdistan Region - Iraq
}

\begin{abstract}
Since 2003, the Kurdistan Region of Iraq has significantly developed in oil and gas sector and has signed about 60 production sharing contracts with international oil companies. There are several points and reasons in Kurdistan oil and gas sector that attract the companies to sign contracts. The Kurdistan Region holds about 45 billion barrels of oiland 2.8-5.7 trillion cubic metres of estimated gas reserves; its oil production has grown progressively and currently exports over 400,000 barrels of oil per day.Kurdistan has its own pipeline with capacity of 1 million barrels of oil per day. Undoubtedly, Kurdistan petroleum contracts are long-term contracts and may last more than 37 years, therefore, they could not easily be reformed. This study attempts to illustrate the geographical division of the blocks of Kurdistan and its reserves to examine whether or not the current situation of the blocks of Kurdistan can be used as an opportunity to reform its oil and gas contracts? This research has clarified that several IOCs have now abandoned their blocks and the KRG has around 24 open license blocks with significant data available and existing wells for most of those blocks. It is therefore a great opportunity for the KRG to reform its oil and gas contracts or to remove the contracts from the complications of several clauses or articles, even to change the type of contract.
\end{abstract}

Keywords: Kurdistan Region of Iraq, Production Sharing Contract, International Oil Company, Kurdistan Petroleum Blocks.

\section{Introduction}

Following Saddam Hussein's removal in 2003, the Kurdistan Region of Iraq (KRI) has developed extremely, particularly in the economic aspect. From an economic point of view, the Kurdistan Regional Government (KRG) has been given the title 'The Other Iraq'. ${ }^{1}$ Kurdistan's 45 billion $^{2}$ to over 50 billion barrels of oil reserves ${ }^{3}$ and 2.8-5.7 trillion cubic meters (tcm; or 100-200 trillion cubic feet) of gas reserves, ${ }^{4}$ is the most important reason for the region's economic development. Kurdistan has developed and become internationally recognized as an extremely attractive petroleum province with significant potentials.

\footnotetext{
${ }^{1}$ M M Gunter, 'Iraqi Kurdistan's Two Contrasting Economic Images' (2012)6(1) International Journal of Contemporary Iraqi Studies 89-95.

${ }^{2}$ KRG, 'Statement on Oil \& Gas Policy by the Kurdistan Regional Government'

<http://www.krg.org/a/d.aspx?1=12\&a=46337> accessed 12 June 2019.

${ }^{3}$ Proactive Investors: United Kingdom, 'Kurdistan Region of Iraq - Land of Opportunity'

<https://www.proactiveinvestors.co.uk/companies/news/258438/kurdistan-region-of-iraq-land-of-opportunity-10165.html> accessed 12 June 2019.

${ }^{4}$ D Tas, 'Petroleum Development in the Kurdistan Region of Iraq: A Struggle Over Competency' (2011) 215 International Energy Law Review 1-19.
} 
Moreover, since 2003, the KRG has signed a significant number of production sharing contracts (PSCs) with small and major international oil companies (IOCs) in the oil and gas sector. ${ }^{5}$ Consequently, several IOCs have engaged in oil and gas production. The oil production process started in Taq Taq (Kewa Chirmila block) with 395,945 barrels of oil in 2003. ${ }^{6}$ Day to day, the number of Kurdistan oil and gas producing blocks have increased and reached to 12 blocks in $2013^{7}$ as well as a number of IOCs are still exploring and drilling. Kurdistan oil production has grown progressively and sustainably; it was more that 500,000 barrels of oil per day (bopd) in 2015 and 2016. Additionally, the KRG has its own pipeline, which is called the Kurdistan Crude Pipeline, to export oil to Turkey with 1 million bopd capacity. ${ }^{8}$ It also has a number of oil tie-in domestic pipelines and currently exports over 400,000 bopd.

However, petroleum contracts are known as long-term contracts, for instance, the KRG's PSCs have been signed for 25 years and may last more than 37 years due to the extending right of contractors ${ }^{9}$ with lack of renegotiation clause. Clearly the KRG would not easily reform its signed oil and gas contracts over the period mentioned. This study therefore attempts to answer a significant question: According to the new geographical division of Kurdistan's blocks, does the KRG have the opportunity to reform its oil and gas contracts or extricate the contracts from the complications of several clauses or articles?

The study is divided into three main sections, to answer the question. The study is introduced on the first section. The second section illustrates geographical division, the current situation and reserves of Kurdistan's blocks. The chapter will conclude on the third section.

\section{Kurdistan Region Oil and Gas Reserves and Geographical Division of its Blocks}

The Kurdistan Region of Iraq (KRI) holds about 45 billion barrels of oil in reserves. In other words, it has estimated oil reserves of 45 billion barrels. ${ }^{10}$ With the mentioned reserves, if the Kurdistan Region was a country, it would be seen ranked as one of ten countries that have the largest reserves in the world. ${ }^{11}$ It is undoubtable that Kurdistan with reserves of 45 billion barrels of oil has unique opportunities for onshore discoveries and has attracted the attention of a large number of small, medium as well as super-major international petroleum companies.

On the other hand, the massive natural gas field of the Kurdistan Region has made it as a potential important player in global energy security. Kurdistan has about 708 billion cubic metres of proven gas and 2.8-5.7 trillion cubic metres of estimated gas reserves. ${ }^{12}$ The Kurdistan region has two significant gas fields which are Bawi and Miran fields with an estimated of 238 billion cubic metres of natural gas reserves. ${ }^{13}$ In terms of Kurdistan's energy structured domain, as shown in Figure 2.1, there are four main zones. The first one named the Taurus Mountains zone; it contains medium-toheavy oil with large resources and a low-to-medium exploration risk. The second is known as the Taurus Foothills that covers large resources of heavy oil with low geological risk. The Shaikan field operated by the Gulf Keystone has shown the potential of the Taurus Foothills zone. The third zone is the Zagros Foothills zone that surrounds large oil and gas fields with higher gas-to-oil ratios and low geological risk. The significant advantage of this zone is its location, which is close to the Kirkuk-Ceyhan pipeline.

\footnotetext{
${ }^{5}$ C M Blanchard, 'Iraq: Oil and Gas Legislation, Revenue Sharing, and U.S. Policy' CRS Report for Congress, $<$ http://www.fas.org/sgp/crs/mideast/RL34064.pdf> accessed 13 June 2019.

${ }^{6}$ Ministry of Natural Resources, 'Capacity Building Payments Received by KRG from All PSCs and Its Utilisation' <http://mnr.krg.org/images/pdfs/Production\%20Data\%20ENG\%20PDF.pdf> accessed 12 July 2019.

${ }^{7}$ The Oil and Gas Year, The Oil and Gas Year: Kurdistan Region of Iraq 2014 (Wildcat International FZ-LLC, Neuilly Seine 2014) p. 16-17.

${ }^{8}$ F Owtram, 'The Federalization of Natural Resources' in A Danilovich (ed), Iraqi Federalism and the Kurds: Learning to Live Together (Ashgate Publishing Limited, Surrey 2014) PP.113-141.

${ }^{9} \mathrm{R}$ S Salih and M S Salih, 'Procedures of Disputes Resolution Between the Kurdistan Regional Government and International Oil and Gas Companies: Dana Gas and its alliancesas a Case Study (in Kurdish)' (2019)1 Proceeding of The 4th International Legal Issues Conference/ Ishik (Tishk) University 30/4/2019,13-34; also see Oil and Gas Law of the Kurdistan Region- Iraq No. (22) of 2007, Article 37 (First).

${ }^{10}$ The Oil and Gas Year, The Oil and Gas Year: Kurdistan Region of Iraq 2013 (Wildcat International FZ-LLC, Neuilly Seine 2013) p.29; The Oil and Gas Year, The Oil and Gas Year: Kurdistan Region of Iraq 2011(Wildcat International FZ-LLC, Neuilly Seine 2011) p. 55.

${ }^{11}$ The Oil and Gas Year, The Oil and Gas Year: Kurdistan Region of Iraq 2014, op. cit., p. 39.

${ }^{12}$ ibid., p. 86; K A Auzer, Institutional Design and Capacity to Enhance Effective Governance of Oil and Gas Wealth: The Case of Kurdistan Region (Springer Nature Singapore Pte Ltd: Gateway East, Singapore 2017) p. 119.

${ }^{13}$ ibid. 
The last zone, which is the Zagros Mountains, comprises a higher propensity to gas finds with medium to high technical risk and cost. ${ }^{14}$ Ashti Hawrami, the KRG's former minister of natural resources stated that "the Zagros belt in Kudistan is rich in natural gas as well as oil and there have been a lot of gas discoveries in the disputed territories."

Figure 2.1: Structural Domain of the Kurdistan Region's Oil and Gas Resources

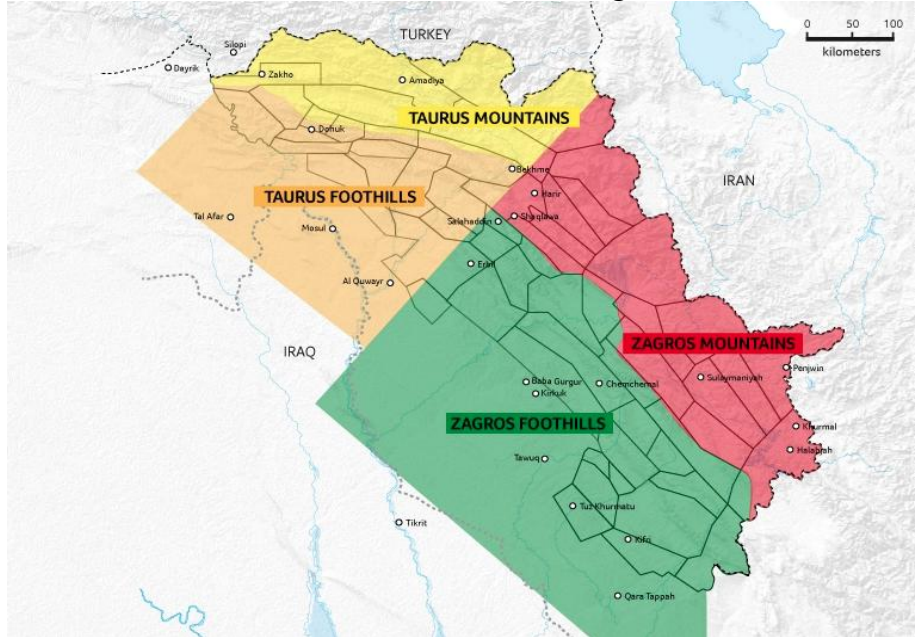

Source: Ministry of Natural Resources, 'Structural Domain'<http://mnr.krg.org/index.php/en/structural-domain> accessed 20 June 2019.

The KRG depends on blocks system that has divided the four zones into a number of different exploration and production blocks. Since the beginning of the Kurdistan oil and gas sector's activities, number and size of these blocks have being changed several times due to acquiring and relinquishing blocks by IOCs and redesigning them by the KRG. At the begging, Kurdistan had 57 oil and gas blocks. The KRG has granted a lot of licences to IOCs for oil and gas activities in different phases. For instance, until 2005, just Seven licences were granted by the KRG and there were 50 open blocks ${ }^{16}$ and until 2013, 52 different blocks had been granted and there were just five open blocks. ${ }^{17}$ However, in 2014, the number of Kurdistan oil and gas blocks rose to 66 blocks and there were 16 open blocks. ${ }^{18}$ Unfortunately, since 2014 many IOCs have relinquished their blocks and Kurdistan has faced a dramatic rise in the number of relinquished blocks. ${ }^{19}$ As mentioned earlier, the blocks have been granted to international oil and gas companies in different phases. Hence, this section explains all blocks as well as their current situation and operators in a number of different subsections, as follow:

\subsection{The Early Movers: Prior to the 2005 Iraqi Constitution}

At the beginning of Kurdistan oil and gas activities, only seven blocks were granted to a number of international petroleum companies. The seven blocks, as depicted in Figure 2.2, are Tawke, Taq Taq and Kewa Chirmila, Bina Bawi, Dohuk, Shakal, Bawanoor and Erbil blocks.

\footnotetext{
${ }^{14}$ Ministry of Natural Resources, 'Structural Domain' < http://mnr.krg.org/index.php/en/structural-domain> accessed 20 June 2019.

${ }^{15}$ A Hawrami, cited in The Oil and Gas Year, The Oil and Gas Year: Kurdistan Region of Iraq 2009 (Wildcat Publishing Inc., Neuilly Seine 2009) p. 64-65.

${ }^{16}$ The Oil and Gas Year, The Oil and Gas Year: Kurdistan Region of Iraq 2009, op. cit., p. 55.

17 ibid., p. 64-65.

${ }^{18}$ The Oil and Gas Year, The Oil and Gas Year: Kurdistan Region of Iraq 2014, op. cit., p. 42.

${ }^{19}$ The Oil and Gas Year, The Oil and Gas Year: Kurdistan Region of Iraq 2016 (Wildcat International FZ-LLC, Neuilly Seine 2016), p. 29.
} 
Figure 2.2: The Early Movers to Kurdistan

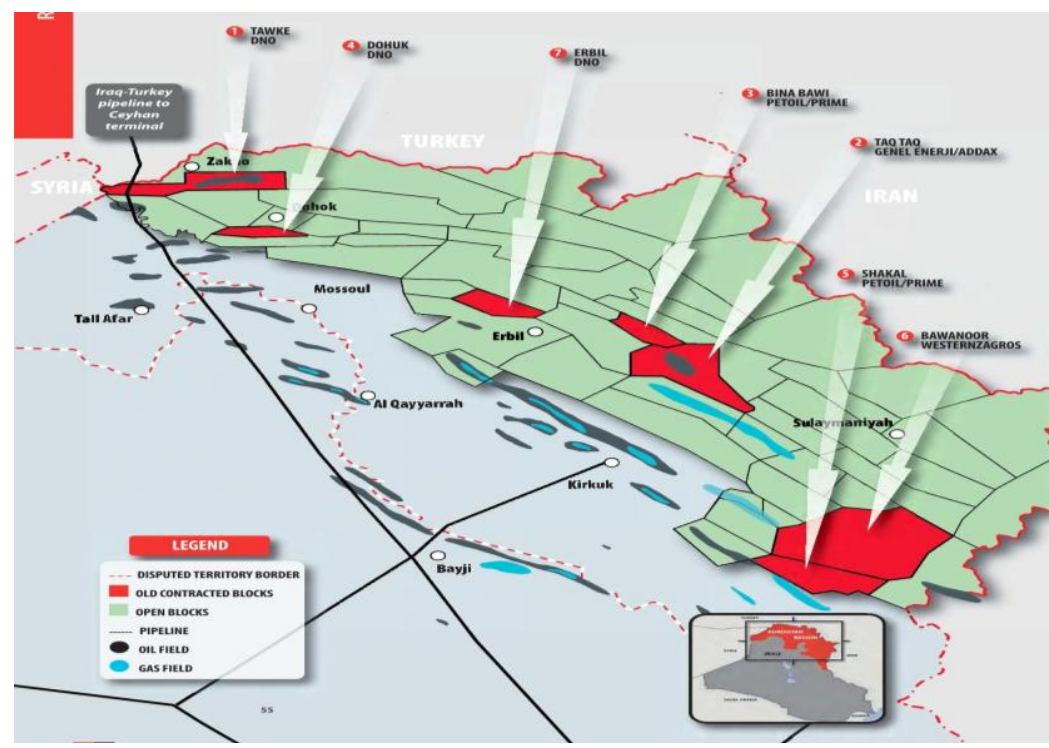

Source: The Oil and Gas Year, The Oil and Gas Year: Kurdistan Region of Iraq 2009 (Wildcat Publishing Inc., France 2009) p. 55.

\subsubsection{Tawke and Taq Taq \& Kewa Chirmila Blocks:}

Tawke block is located in Zaxo district and contains 594 square kilometres of the city. It is estimated to have 1.9 billion oil barrels. ${ }^{20}$ Tawke block's operators are the Norwegian energy company DNO (Det Norske Oljeselskap ASA) with $75 \%$ working interest ${ }^{21}$ and Genel Energy with $25 \% .{ }^{22}$ Also, Taq Taq \& Kewa Chirmila block is located in Taq Taq district, Erbil city and contains about 1.5 billion barrels of oil. ${ }^{23}$ At the beginning, Taq Taq \& Kewa Chirmila was one block and was 951 square kilometres ${ }^{24}$ but in 2014, it has been divided to two blocks:Taq Taq block and Kewa Chirmila block as seen in Figure 2.6. ${ }^{25}$ Taq Taq block's operators are TTOPCO with $80 \%$ net working interest (Genel Energy $44 \%$ \& Addax Petroleum 36\%) and KRG retains a $20 \%$ fully carried interest. ${ }^{26}$ However, Kewa Chirmila block is currently an open licence block. $^{27}$

\subsubsection{Bina Bawi,DohukandShakal Blocks:}

Bina Bawi block lies from Gomaspan strait to Hiran and Nazanin area; it is about 240 square kilometres. ${ }^{28}$ Estimated raw reserves on the block is 201 billion cubic meters (bcm) of raw gas. ${ }^{29}$ Genel Energy with $100 \%$ interest is the only operator of Bina Bawi block. ${ }^{30}$

\footnotetext{
${ }^{20}$ The Oil and Gas Year, The Oil and Gas Year: Kurdistan Region of Iraq 2011, op. cit., p. 60; S J Fathallah, Kurdistan Region's Oil (in Kurdish) (Narin, Erbil 2015) p. 81.

${ }^{21}$ DNO, 'DNO Increases Tawke Stake; Announces Settlement of Kurdistan Receivables' < https://www.dno.no/en/investorrelations/announcements/2017/dno-increases-tawke-stake-announces-settlement-of-kurdistan-receivables/> accessed 4 August 2019.

${ }^{22}$ Genel Energy, 'Tawke - Peshkabir' <https://www.genelenergy.com/operations/kri-production/tawke-peshkabir/>accessed 4 August 2019.

${ }^{23}$ Fathallah, op. cit., p. 97.

${ }^{24}$ The Oil and Gas Year, The Oil and Gas Year: Kurdistan Region of Iraq 2011, op. cit., p. 61; The Oil and Gas Year, The Oil and Gas Year: Kurdistan Region of Iraq 2014, op. cit., p. 48-49.

${ }^{25}$ The Oil and Gas Year, The Oil and Gas Year: Kurdistan Region of Iraq 2014, op. cit., p. 42.

${ }^{26}$ Genel Energy, 'Snapshot of Genel Energy' <https://www.genelenergy.com/about-us/who-we-are/snapshot-of-genelenergy/>accessed 4 August 2019; The Oil and Gas Year, The Oil and Gas Year: Kurdistan Region of Iraq 2014, op. cit., p. 42.

${ }^{27}$ ibid.

${ }^{28}$ The Oil and Gas Year, The Oil and Gas Year: Kurdistan Region of Iraq 2011, loc. cit.

${ }^{29}$ The Oil and Gas Year, The Oil and Gas Year: Kurdistan Region of Iraq 2016, op. cit., p. 59.

${ }^{30}$ Genel Energy, 'Snapshot of Genel Energy', loc. cit. 
Moreover, Dohuk block contains centre and south of Dohuk city and Semel district; it is approximately 162 square kilometres $^{31}$ and is estimated to covers 2.2 billion barrels of oil reserves. ${ }^{32} \% 40$ of its stake was granted to Genel Energy, the same percentages to DNO and KRG held 20\% fully carried interest. ${ }^{33}$ However, Genel Energy and its partner formally relinquished in this block ${ }^{34}$ and currently it is a relinquished block. ${ }^{35}$ Another block that granted to IOCs isShakal. Shakal blocklies in south-eastern fairway of the prolific Zagros Fold belt of Kurdistan region and covers south of Kalar district, Rzgari sub-district and Kfri district. ${ }^{36}$ Its area is about 632 square kilometres ${ }^{37}$ and estimated to have 2billion oil barrels. ${ }^{38}$ However, this block at the beginning was operated by Prime Natural Resources, Petoil, Oil Search and $\mathrm{KRG}^{39}$, but nowadays, Gazprom Neft with $80 \%$ working interest and KRG with the remaining $20 \%$ are operating it. ${ }^{40}$

\subsubsection{Bawanoor and Erbil Blocks:}

Bawanoor blockis divided into two different blocks which are Garmian and Kurdamir blocks as seen in Figure 2.6. The Garmian block also called Kalar-Bawanoor block, covers north of Kalar district, Bawanoor, Sarqala and Shekh Tawilsub-districts. ${ }^{41}$ It is 1780 square kilometres ${ }^{42}$ and estimated oil of this block is about 33 million barrels and 24 bcm or 847 billion cubic feet (bcf) of gas. ${ }^{43}$ Garmian block's operators are Gazprom Neft with $40 \%$ stake, ${ }^{44}$ Westeren Zagrose Ltd. with $40 \%{ }^{45}$ and KRG (back-in interest (BI) $20 \%$ fully carried) ${ }^{46}$ Kurdamir block contains south part of Sangaw sub-district andnorth of Kalar district to Sirwan river and is about 340 square kilometres. ${ }^{47}$ It is estimated to have 5.129 billion barrels of oil which is more than both Ghana and Egypt's oil reserves. ${ }^{48} 40 \%$ of this block is belong to Repsol (Talisman $\left.{ }^{*}\right)^{49}, 40 \%$ to Western Zagros ${ }^{50}$ and BI.20\% fully carried to the KRG. ${ }^{51}$ Lastly, Erbil block, which is

\footnotetext{
${ }^{31}$ The Oil and Gas Year, The Oil and Gas Year: Kurdistan Region of Iraq 2011, op. cit., p. 60.

${ }^{32}$ Fathallah, op. cit., p. 81.

${ }^{33}$ The Oil and Gas Year, The Oil and Gas Year: Kurdistan Region of Iraq 2014, op. cit., p. 48-49.
}

${ }^{34}$ Genel Energy, 'Trading and operations update: 24 January 2017' [Report]

<https://www.genelenergy.com/media/2021/genel-trading-and-operations-update-jan-2017-final.pdf> accessed 7 August 2019.

${ }^{35}$ Iraq Databank, Summary of Kurdistan Region Exploration Block Activity, 2014 to 2016'

<http://www.iraqdatabank.org/storage/app/uploads/public/59d/37a/b2c/59d37ab2cd013842088027.pdf?i=1> accessed 5 August 2019.

${ }^{36}$ Fathallah, op. cit., p. 103.

${ }^{37}$ The Oil and Gas Year, The Oil and Gas Year: Kurdistan Region of Iraq 2011, op. cit., p. 61; The Oil and Gas Year, The Oil and Gas Year: Kurdistan Region of Iraq 2014, op. cit., p. 48-49.

${ }^{38}$ Fathallah, loc. cit.

${ }^{39}$ The Oil and Gas Year, The Oil and Gas Year: Kurdistan Region of Iraq 2009 op. cit., p. 56

${ }^{40}$ The Oil and Gas Year, The Oil and Gas Year: Kurdistan Region of Iraq 2013, op. cit., p. 64-65; The Oil and Gas Year, The Oil and Gas Year: Kurdistan Region of Iraq 2014, op. cit., p. 42; Gazprom Neft, 'Gazprom Neft Expands Oil Production in The Kurdistan Region of Iraq' <https://www.gazprom-neft.com/press-center/news/2664279/> accessed 9 July 2019.

${ }^{41}$ Fathallah, op. cit., p. 104.

${ }^{42}$ The Oil and Gas Year, The Oil and Gas Year: Kurdistan Region of Iraq 2014, op. cit., p. 48-49.

${ }^{43}$ The Oil and Gas Year, The Oil and Gas Year: Kurdistan Region of Iraq 2011, loc. cit.

${ }^{44}$ Gazprom Neft, loc. cit.

${ }^{45}$ Western Zagros, 'Garmian Block (WesternZagros 40\% Working Interest'

<http://www.westernzagros.com/ouroperations/garmian-block/> accessed 4 August 2019.

${ }^{46}$ The Oil and Gas Year, The Oil and Gas Year: Kurdistan Region of Iraq 2009, loc. cit.; The Oil and Gas Year, The Oil and Gas Year: Kurdistan Region of Iraq 2013, loc. cit.

${ }^{47}$ The Oil and Gas Year, The Oil and Gas Year: Kurdistan Region of Iraq 2014, loc. cit.

${ }^{48}$ Fathallah, op. cit., p. 103.

*In 2015, Spain's Repsol acquired Canadian's Talisman Energy Inc. and in 2016, changed its name to Repsol Oil \& Gas Canada Inc. Sources: Repsol, 'Acquisation of Talisman Energy'

<https://www.repsol.com/imagenes/global/es/Acquisition_of_Talisman_Energy_Repsol_Market_Release_tcm13-58475.pdf> accessed 7 August 2019; BOE Report, ' Talisman Energy Inc. and Related Canadian Partnerships Announce Name Changes' <https://boereport.com/2016/01/04/talisman-energy-inc-and-related-canadian-partnerships-announce-name-changes/> accessed 7 August 2019.

${ }^{49}$ Repsol, 'Iraq' <https://www.repsol.com/en/repsol-worldwide/asia/iraq/index.cshtml> accessed 9 July 2019.

${ }^{50}$ Western Zagros, 'Kurdamir Block (WesternZagros 40\% Working Interest'

<http://www.westernzagros.com/ouroperations/kurdamir-block/> accessed 4 August 2019. 
located in western part of Kurdistan region, covers northwest of Erbil and Bastora area. It is 313 square kilometres ${ }^{52}$ and estimated to have 1 billion oil barrels. ${ }^{53}$ Currently, DNO with 40\%, Gas Plus Erbil Ltd. with the same percentage of stake and KRG with BI. $20 \%$ fully carried are operating the block. ${ }^{54}$ It can be noted that at this phase 50 blocks were open and had not been granted to any companies.

\subsection{The First Wave after Regional Oil and Gas Law (September 2007):}

After issuing the Kurdistan Oil and Gas Law in 2007, as a first wave, KRG granted other eight oil and gas blocks to international petroleum companies. Figure 2.3 shows these eight blocks which are Ain Sifni, Miran, Shaikan, Sangaw North, Rovi \&Sarta, Akri-Bijeel, Hawler Contract Area and Mala Omer \& Shorish blocks.

Figure 2.3: Granted Blocks in The First Wave After Regional Oil and Gas Law

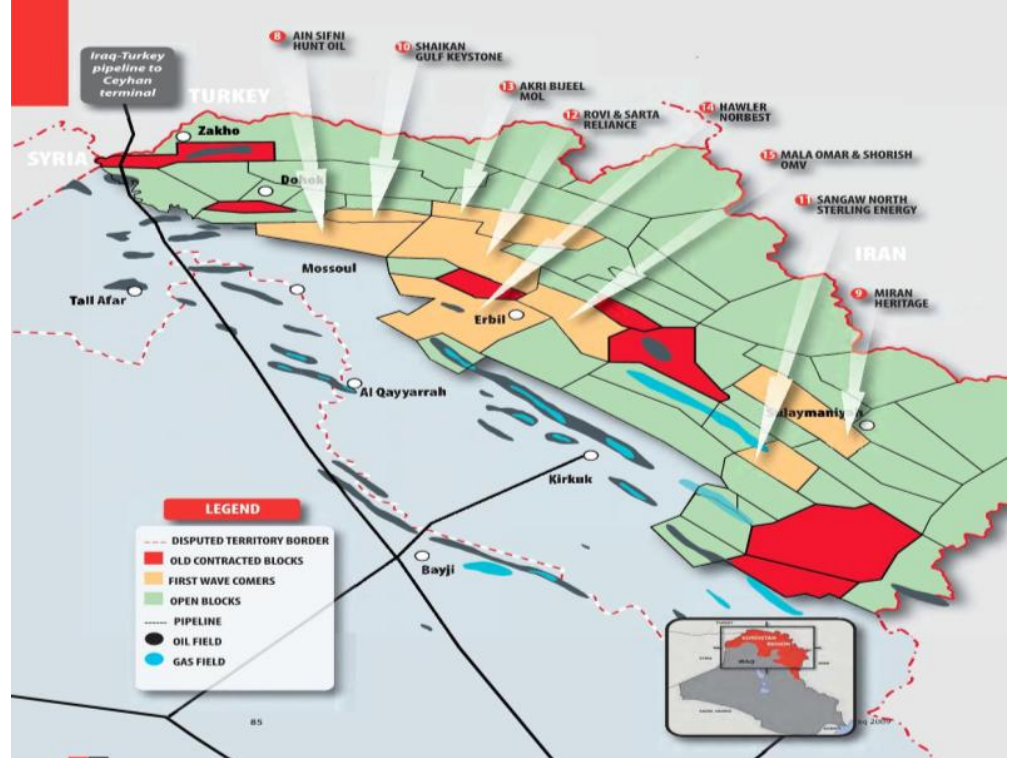

Source: The Oil and Gas Year, The Oil and Gas Year: Kurdistan Region of Iraq 2009 (Wildcat Publishing Inc., France 2009) p. 85.

\subsubsection{Ain Sifni,Miranand Shaikan Blocks:}

Ain Sifniblock is located in the east of Mossoul city and covers Ain Safini area that is 549 square kilometres. ${ }^{55}$ The block contains approximately 1 billion oil barrels. ${ }^{56}$ The first production sharing contract (PSC) signed by KRG since Oil and Gas Law of Kurdistan Region wasissued, was for this block. At the first, 100\% of this block was granted to Hunt Oil Company of the Kurdistan Region which is subsidiary of Hunt Oil Company (USA) and KRG retained a 25\% back-in right option after declaration of commerciality. ${ }^{57}$

However, currently, it is being operated by Hunt Oil (60\%), Afren Company (20\%) and KRG BI. (20\%) fully carried. ${ }^{58}$ In terms of Miran block,it starts from Tasluja, and covers west of Dukan-Sulaymaniyah main road, a part of Aghjalar sub-district, Bazian town, Razan resort that is about 1015 square kilometres. ${ }^{59}$ Miran block hasreserves estimated around $122 \mathrm{bcm}_{\text {of }}$ gas $^{60}$ and 95 million barrels of oil. ${ }^{61}$

\footnotetext{
${ }^{51}$ The Oil and Gas Year, The Oil and Gas Year: Kurdistan Region of Iraq 2013, loc. cit.; The Oil and Gas Year, The Oil and Gas Year: Kurdistan Region of Iraq 2014, op. cit., p. 42.

${ }^{52}$ The Oil and Gas Year, The Oil and Gas Year: Kurdistan Region of Iraq 2011, op. cit., p. 60.

${ }^{53}$ Fathallah, op. cit., p. 98.

${ }^{54}$ DNO, 'Kurdistan Region of Iraq' < https://www.dno.no/en/operations/where-we-operate/kurdistan1/> accessed 4 August 2019.

${ }^{55}$ The Oil and Gas Year, The Oil and Gas Year: Kurdistan Region of Iraq 2014 op. cit., p. 48-49.

${ }^{56}$ Fathallah, op. cit., p. 84.

${ }^{57}$ The Oil and Gas Year, The Oil and Gas Year: Kurdistan Region of Iraq 2009 op. cit., p. 86.

58 The Oil and Gas Year, The Oil and Gas Year: Kurdistan Region of Iraq 2013, loc. cit.; The Oil and Gas Year, The Oil and Gas Year: Kurdistan Region of Iraq 2016, op. cit., p. 31-32.

${ }^{59}$ The Oil and Gas Year, The Oil and Gas Year: Kurdistan Region of Iraq 2011, op. cit., p. 61.

${ }^{60}$ The Oil and Gas Year, The Oil and Gas Year: Kurdistan Region of Iraq 2016, loc. cit.

${ }^{61}$ The Oil and Gas Year, The Oil and Gas Year: Kurdistan Region of Iraq 2014, op. cit., p. 67. 
Currently, it is being operated by Genel Energy with $100 \%$ working interest. ${ }^{62}$ However, Figure 2.6 shows that a part of this block has been separated as an open licence block that called S.E Miran block. ${ }^{63}$ Moreover, Shaikan block is located in Dohuk city, $90 \mathrm{KM}$ northwest of Erbil city; it comprises Shaikan district and is approximately 283 square kilometres. ${ }^{64}$ Shaikan block is estimated to have about 10.5 billion barrels of oil reserves which is more than Ecuador's oil reserves. ${ }^{65}$ Gulf Keystone with $75 \%$, Texas Keystone with 5\%, ${ }^{66}$ Kalegran (MOL's $100 \%$ subsidiary) with $20 \%{ }^{67}$ are producing in this block. ${ }^{6}$

\subsubsection{Sangaw North and Rovi \&Sarta Blocks:}

Sangaw North block is located approximately $140 \mathrm{KM}$ southeast of Erbil city, north of Sangaw sub-district in Chemchemal district. It is 492 square kilometres and estimated to have 6.163 billion barrels of estimated oil which is more than Oman's oil reserves. ${ }^{69}$ At the beginning, the operator of this block was Sterling Energy with initial working interest $100 \%$. Then, Sterling Energy controlled a $66.66 \%$ interest after farming out a $33.33 \%$ interest to Addax Petroleum Corporation. In October 2008, KRG's third party interest of $20 \%$ was subsequently assigned to the KNOC (Korean National Oil Company) by reducing Addax and Sterling's interest. ${ }^{70}$ However, this block was relinquished and according to the 'The Oil \& Gas Year: Kurdistan Region of Iraq 2013 and 2014', it is an open licence block. ${ }^{71}$ Another block is Rovi \&Sarta block. This block is located in north of Kurdistan Region. It covers north part of Barda Rash district and southern part of Akri district. ${ }^{72}$ The block is adjacent to the Shaikan block; Rovi is about 517 and Sarta is 607 square kilometres. ${ }^{73}$ This block is estimated to have 1 billion barrels of oil, according to Chevron Company's report. ${ }^{74}$ At the beginning, the block was one block and was granted to an Indian company which was Reliance Exploration and Production DMCC with $100 \%$ working interest. ${ }^{75}$ After a while, however, it has been divided into two blocks:Rovi and Sarta, as seen in Figure 2.6. In Sarta block, Chevron (an American company) holds 50\% of the stake, ${ }^{76}$ Genel Energy 30\% and KRG 20\%. ${ }^{77}$ However, Chevron relinquished Rovi block at the end of $2015^{78}$ and currently it is a relinquished block. ${ }^{79}$

2.2.3 Akri-Bijeel, Hawler and Mala Omer \& Shorish Blocks:

Akri-Bijeel block covers Akri district and Bijeel sub-district to Bexma strait. It is approximately 889 square kilometres ${ }^{80}$ and estimated to have more than 1 billion barrels of oil. ${ }^{81}$ The block was operated by MOL (Hungarian Oil and Gas Company) with 51.2\% interest, Gulf Keystone with 12.8\%, KRG BI. with 20\% part carried and 16\% net thirdparty interest. ${ }^{82}$ However, the operators signed the relinquishment and termination agreement on 31 December $2015 .{ }^{83}$

\footnotetext{
${ }^{62}$ Genel Energy, 'Miran'<https://www.genelenergy.com/operations/kri-development/miran/>accessed 4 August 2019.

${ }^{63}$ The Oil and Gas Year, The Oil and Gas Year: Kurdistan Region of Iraq 2014, op. cit., p. 42.

${ }^{64}$ The Oil and Gas Year, The Oil and Gas Year: Kurdistan Region of Iraq 2011, op. cit., p. 60.

${ }^{65}$ Fathallah, op. cit., p. 83.

${ }^{66}$ Gulf Keystone Petroleum, 'Kurdistan Region of Iraq'

<https://www.gulfkeystone.com/operations/shaikan'\%20and\%20'x'='x> accessed 4 August 2019.

${ }^{67}$ MOL Group, 'Kurdistan'< $<$ https://molgroup.info/en/our-business/exploration-and-production/kurdistan> accessed 4 August 2019.

${ }^{68}$ Rigzone, Gulf Keystone Signs PSC with KRG for Stake in Shaikan Block'

<https://www.rigzone.com/news/oil_gas/a/52564/gulf_keystone_signs_psc_with_krg_for_stake_in_shaikan_block/> accessed 4 August 2019.

${ }^{69}$ Fathallah, op. cit., p. 101.

${ }^{70}$ The Oil and Gas Year, The Oil and Gas Year: Kurdistan Region of Iraq 2009, loc. cit.

${ }^{71}$ The Oil and Gas Year, The Oil and Gas Year: Kurdistan Region of Iraq 2013, loc. cit.; The Oil and Gas Year, The Oil and Gas Year: Kurdistan Region of Iraq 2014, loc. cit.

${ }^{72}$ Fathallah, op. cit., p. 84.

${ }^{73}$ The Oil and Gas Year, The Oil and Gas Year: Kurdistan Region of Iraq 2011, loc. cit.

${ }^{74}$ Fathallah, loc. cit.

${ }^{75}$ The Oil and Gas Year, The Oil and Gas Year: Kurdistan Region of Iraq 2009, loc. cit.

${ }^{76}$ Chevron, 'Iraq' < https://www.chevron.com/worldwide/iraq> accessed 4 August 2019.

${ }^{77}$ Genel Energy, 'Snapshot of Genel Energy', loc. cit.

${ }^{78}$ R Bousso and D Zhdannikov, ' Chevron Drills Oil Well in Iraqi Kurdistan Area after Two-Year Gap' $<$ https://www.reuters.com/article/us-chevron-exploration/chevron-drills-oil-well-in-iraqi-kurdish-area-after-two-year-gapsources-idUSKCN1BV1UG> 6 August 2019.

${ }^{79}$ Iraq Databank, loc. cit.

${ }^{80}$ The Oil and Gas Year, The Oil and Gas Year: Kurdistan Region of Iraq 2011, loc. cit.

${ }^{81}$ Fathallah, op. cit., p. 83.

${ }^{82}$ The Oil and Gas Year, The Oil and Gas Year: Kurdistan Region of Iraq 2013, loc. cit.
} 
As shown in Figure 2.6, two blocks have been separated from Akri-Bijeel block: Bekhme block which is an open licence area and another open licence block. ${ }^{84}$ Other contracted block is Hawler Contract Area block also known as Hawler block is located in the capital city of Kurdistan Region and covers Erbil city, plain of Erbil, Makhmur path and Kalak sub-district which is about 1531 square kilometres. ${ }^{85}$ Hawler block is estimated to contain at least 1 billion barrels of oil. ${ }^{86}$ Currently, the operators of the block are Oryx Petroleum which has a $65 \%$ participating and working interest, ${ }^{87}$ Korea National Oil Corporation(KNOK) with $15 \%$ and the KRGowns the remaining $20 \%{ }^{88}$ Now, almost half of this block has been made as an open licence block as seen in Figure 2.6. ${ }^{89}$ Last granted block in this phase is Mala Omer \& Shorish block. At the first, the block was known as one block and was granted to OMV Petroleum Exploration GMBH with $100 \%$ working interest and KRG had a $25 \%$ back-in rights option after declaration of commerciality. ${ }^{90}$ Nevertheless, as shown in Figure 2.6, the block was divided into two separate blocks: Mala Omerblock and Shorish block that both blocksare located in Erbil city. Mala Omerblock is located in south east of Erbil city and is about 285 square kilometres. Its oil is estimated to be 500 million barrels. In terms of Shorish block, it covers north east of Erbil city, Degala sub-district to Gomaspan strait and is about 526 square kilometres. ${ }^{91}$ But OMV handed both blocks back to the $\mathrm{KRG}^{92}$ and currently, both blocks are open licence blocks.

\subsection{The Second Wave After Regional Oil and Gas Law:}

After issuing the Kurdistan Oil and Gas Law in 2007, as a second wave, KRG granted other seven blocks to international oil and gas companies. Figure 2.4 shows the seven blocks which are Sindi-Amedi, Atrush, Bazian, Sarsang, Khor Mor, Chemchemal blocks and Block 39 (Topkhana).

Figure 2.4: Granted Blocks in The Second Wave After Regional Oil and Gas Law

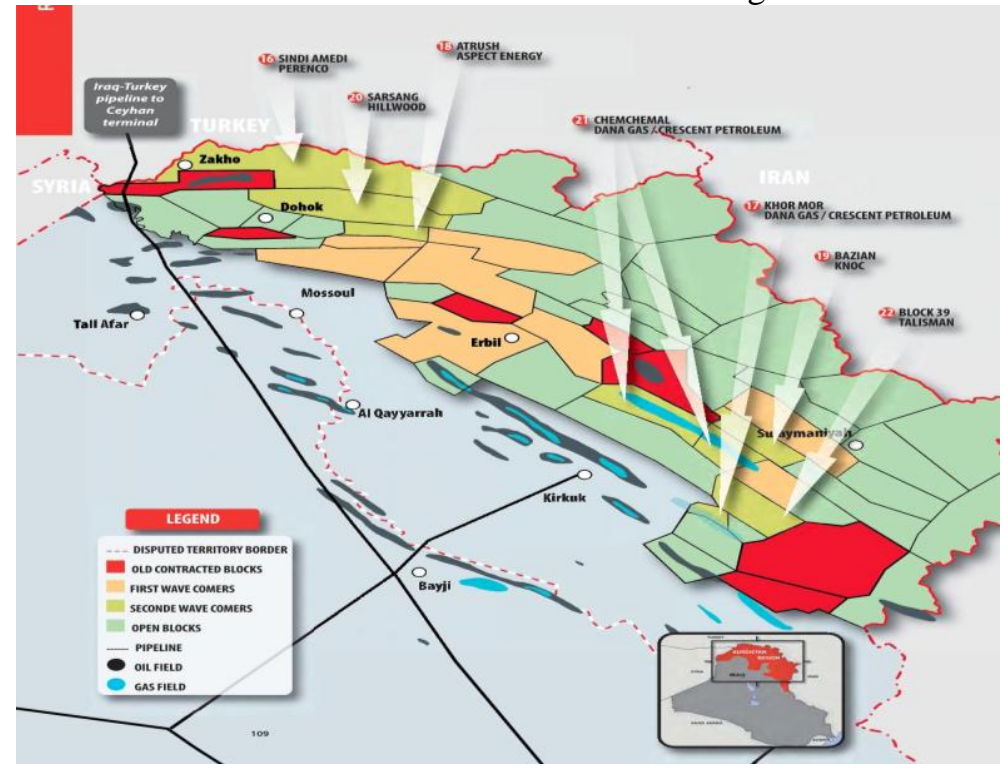

Source: The Oil and Gas Year, The Oil and Gas Year: Kurdistan Region of Iraq 2009(Wildcat Publishing Inc., 2009) p. 109.

\footnotetext{
${ }^{83}$ MOL Group, Relinquishment of the Akri-Bijeel Block in the Kurdistan Region of Iraq' $<$ https://molgroup.info/en/investorrelations/investor-news/relinquishment-of-the-akri-bijeel-block-in-the-kurdistan-region-of-iraq> accessed 5 August 2019.

${ }^{84}$ The Oil and Gas Year, The Oil and Gas Year: Kurdistan Region of Iraq 2014, loc. cit.

${ }^{85}$ Fathallah, op. cit., p. 98.

${ }^{86}$ The Oil and Gas Year, The Oil and Gas Year: Kurdistan Region of Iraq 2014, op. cit., p. 72.

${ }^{87}$ Oryx Petroleum, 'Kurdistan Region of Iraq' <https://www.oryxpetroleum.com/en/operations/iraq.php> accessed 9 July 2019.

${ }^{88}$ The Oil and Gas Year, The Oil and Gas Year: Kurdistan Region of Iraq 2013, loc. cit.; The Oil and Gas Year, The Oil and Gas Year: Kurdistan Region of Iraq 2014, op. cit., p. 42; KNOK, 'Iraq'

<https://www.knoc.co.kr/ENG/sub03/sub03_1_5_1.jsp> accessed 9 July 2019.

${ }^{89}$ The Oil and Gas Year, The Oil and Gas Year: Kurdistan Region of Iraq 2014, loc. cit.

${ }^{90}$ The Oil and Gas Year, The Oil and Gas Year: Kurdistan Region of Iraq 2009, loc. cit.

${ }^{91}$ Fathallah, op. cit., p. 99.

${ }^{92} \mathrm{P}$ Osgood, 'OMV to Relinquish two blocks in Iraqi Kurdidstan' < https://www.iraqoilreport.com/news/omv-to-relinquishtwo-blocks-in-iraqi-kurdistan-9113/> accessed 6 August 2019.
} 


\subsubsection{Sindi-Amedi and Atrush Blocks:}

Sindi-Amedi block covers Amedi district, plain of Sindi and north of Zakhodistrict. The block is approximately 2358 square kilometres ${ }^{93}$ and it was firstly granted to Stan Limited which is a France Company. ${ }^{94}$ Then, the block was divided into two blocks: Sindi-Amedi East and Sindi-Amedi West as seen Figure 2.6. In 2013, Sindi-Amedi East was being operated by Perenco (30.94\% of interest) a French company, Oryx Petroleum (25.31\%), KRG (BI. 25\% part carried) and $18.75 \%$ net third part interest. Also, Sindi-Amedi West block was an open licence block. ${ }^{95}$ However, Sindi-Amedi block is now one block and a relinquished block. ${ }^{96}$ Furthermore, Atrush block covers Atrush sub-district in Dohuk city and is about 269 square kilometres. ${ }^{97}$ It is estimated to have about 2.8 billion barrels of oil reserves. ${ }^{98}$ The block's operators are TAQA with $47.4 \%$ and General Explorations Partners, Inc. (a wholly owned subsidiary of ShaMaran PetroleumCrop of Canada) with $27.6 \%,{ }^{99}$ (after completing the acquisition of Marathon's $15 \%$ working interest in 2018) ${ }^{100}$ and KRG holds $25 \%$ working interest of the block. ${ }^{101}$

\subsubsection{Bazianand Sarsang Blocks:}

Bazian blockin located in Sulaymaniyeh city and covers Sagrma mountain, west of Bazian, Take town and a part of Aghjalar sub-district in Chemchemal district. Bazian block is approximately 473 square kilometres and its estimated oil reserves is about 1.178 billion barrels of oil. ${ }^{102}$ It was being operated by KNOK-Bazian (80\%) and KRG (BI.20\% part carried). ${ }^{103}$ However, KNOC pulled out of this block in $2014{ }^{104}$ and currently it is a relinquished block. ${ }^{105}$ Other contracted block in this phase is Sarsang block. The blockcontains Sarsang sub-district, Swaratuka, north east of Dohuk city and is about 1085 square kilometres. ${ }^{106}$ It is estimated to have 2 billion barrels of oil reserves. ${ }^{107}$ At the beginning the only operator of this block was HKN Energy Ltd (a USA company). ${ }^{108}$ However, HKN Energy Ltd. now holds a 62 $\%$ stake (after acquired Marathon's entire interest which was 20\% in August 2018), ${ }^{109}$ TEPKRI Sarsang A/S (subsidiary of TOTAL S.A.) owns a $18 \%$ stake $^{110}$ with the remaining $20 \%$ interest held by the KRG. ${ }^{111}$

\subsubsection{Khor Mor,Chemchemal and Block 39:}

\footnotetext{
${ }^{93}$ Fathallah, op. cit., p. 80.
}

${ }^{94}$ The Oil and Gas Year, The Oil and Gas Year: Kurdistan Region of Iraq 2009, op. cit., p. 110.

${ }^{95}$ The Oil and Gas Year, The Oil and Gas Year: Kurdistan Region of Iraq 2013, loc. cit.

${ }^{96}$ The Oil and Gas Year, The Oil and Gas Year: Kurdistan Region of Iraq 2016, op. cit., p. 31-32.

${ }^{97}$ The Oil and Gas Year, The Oil and Gas Year: Kurdistan Region of Iraq 2011, op. cit., p. 60

${ }^{98}$ ShaMaran Petroleum Crop, 'Atrush Project' <https://www.shamaranpetroleum.com/operations/atrush-project/> accessed 6 August 2019.

${ }^{99}$ ShaMaran Petroleum Crop, loc. cit. and ShaMaran Petroleum Crop, 'Oil Exploration and Development in Iraqi Kurdistan'<https://www.shamaranpetroleum.com> accessed 6 August 2019.

${ }^{100}$ ShaMaran Petroleum Crop, 'ShaMaran to Acquire Additional 7.5\% Stake in Atrush'

$<$ https://www.shamaranpetroleum.com/news/shamaran-to-acquire-additional-7-5-stake-in-atrus-122702/> accessed 6 August 2019; Rebuilding Iraq, 'TAQA and ShaMaran Petroleum Acquire Atrush Stake from Marathon Oil'

<https://rebuildingiraq.net/news/view/102384-TAQA-and-ShaMaran-Petroleum-Acquire-Atrush-Stake-from-Marathon-Oil> accessed 6 August 2019

${ }^{101}$ The Oil and Gas Year, The Oil and Gas Year: Kurdistan Region of Iraq 2014, loc. cit.

${ }^{102}$ Fathallah, op. cit., p. 105.

${ }^{103}$ The Oil and Gas Year, The Oil and Gas Year: Kurdistan Region of Iraq 2013, loc. cit.; The Oil and Gas Year, The Oil and Gas Year: Kurdistan Region of Iraq 2014, loc. cit.

${ }^{104}$ Min-hee, 'KNOC Pulls Out of Iraq's Sangaw Soth Oil Field Project'

<http://www.businesskorea.co.kr/news/articleView.html?idxno=15631> accessed 5 August 2019; J Lee, 'KNOC drops

Sangaw South Project'<https://www.iraq-businessnews.com/2016/09/05/knoc-drops-sangaw-south-project/> accessed 5

August 2019.

${ }^{105}$ Iraq Databank, loc. cit.

${ }^{106}$ The Oil and Gas Year, The Oil and Gas Year: Kurdistan Region of Iraq 2011, loc. cit.

${ }^{107}$ Fathallah, op. cit., p. 82.

${ }^{108}$ The Oil and Gas Year, The Oil and Gas Year: Kurdistan Region of Iraq 2009, loc. cit.

${ }^{109}$ HKN Energy Ltd., 'Financial Statements: December 31, 2018 and 2017' <https://www.hknenergy.com/wp-

content/uploads/2019/04/FY18_HKNEnergyLtd_FS-1.pdf > accessed 7 August 2019.

${ }^{110}$ TOTAL, 'TOTAL in Iraq' < https://www.total.com/en/iraq-> accessed 7 August 2019.

${ }^{111}$ HKN Energy Ltd., 'Operations in The Kurdistan Region of Iraq' $<$ https://www.hknenergy.com/operations/> accessed 7 August 2019. 
The first two blocks have been granted to the same companies. Khor Mor block is located in Qadr Karam sub-district in Chemchemal district and is about 510 square kilometres. ${ }^{112}$ This block has estimated recoverable gas reserves of approximately $58.8 \mathrm{bcm}^{113}$ and was operated by Crescent Petroleum and Dana Gas (two UAE companies) in 50:50\% interest. ${ }^{114}$ Each company sold $10 \%$ of their stakes to OMV of Austria and MOL of Hungary. In 2015, the consortium welcomed RWEST of German; Crescent Petroleum andDana Gas sold 5\% of their stakes to the RWE. ${ }^{115}$ All companies together are named Pearl Petroleum Company Ltd. The interest of each company is as follows: Crescent Petroleum $35 \%$,Dana Gas 35\%, OMV 10\%, MOL 10\% and RWE 10\%. ${ }^{116}$ Also, Chemchemal block is located in south east of Kurdistan Region, near Kirkuk city and covers Chemchemal district. The area of this block is approximately 1169 square kilometres. Despite oil, it contains a great gas field. The field is about 80 kilometres length and 10 kilometres wide and contains more than $3 \mathrm{tcm}$ gas which is more than Kazakhstan reserves. ${ }^{117}$ As the Khor Mor block, Chemchemal block was operated by Crescent Petroleum and Dana Gas in 50:50\% interest. ${ }^{118}$ Then, the companies sold $10 \%$ of their stakes to OMV and MOL, and after that, they again sold 5\% of their stakes to the RWE in $2015 .{ }^{119}$ The interest of each company is as follows: Crescent Petroleum 35\%,Dana Gas 35\%, OMV 10\%, MOL 10\% and RWE $10 \%{ }^{120}$ Last block that is granted in this phase is Block 39.The block is also called Topkhana block and it is 670 square kilometres. ${ }^{121}$ It is located in south of Kurdistan Region. Topkhana block is operated by Repsol with $80 \%$ interest and the KRG with BI.20\% fully carried. ${ }^{122}$

\subsection{The Third Wave After Regional Oil and Gas Law:}

At third wave, KRG granted other twelve blocks to international oil and gas companies. The twelve blocks, as shown in Figure 2.5, are Ber Bahr, Barda Rash, Chia Surkh (Block 44), Sheikh Adi, Khalakan, Taza (Block 42), Qush Tappa, Al Qush, Baranan (Block 9), Pulkhana Area, Sangaw South and Qara Dagh.

Figure 2.5: Granted Blocks in The Third Wave After Regional Oil and Gas Law

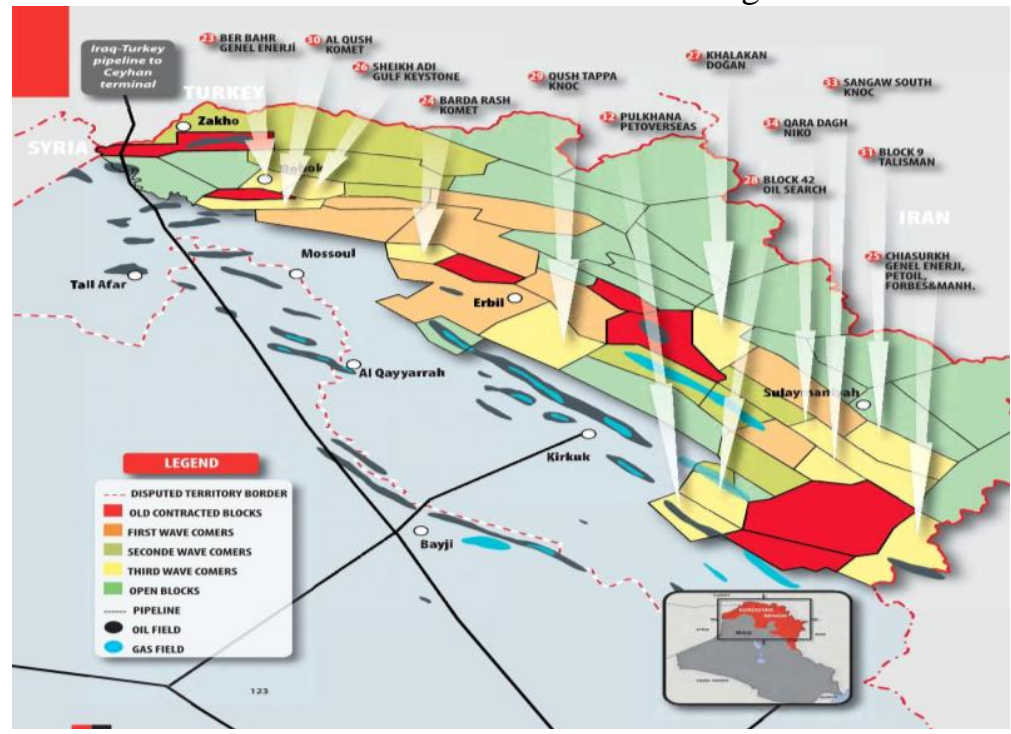

Source: The Oil and Gas Year, The Oil and Gas Year: Kurdistan Region of Iraq 2009(Wildcat Publishing Inc., 2009) p. 123.

\footnotetext{
${ }^{112}$ Fathallah, op. cit., p. 101.

113 The Oil and Gas Year, The Oil and Gas Year: Kurdistan Region of Iraq 2009, op. cit., p. 139; The Oil and Gas Year, The Oil and Gas Year: Kurdistan Region of Iraq 2011, op. cit., p. 61.

114 The Oil and Gas Year, The Oil and Gas Year: Kurdistan Region of Iraq 2009, op. cit., p. 110.

${ }^{115}$ Pearl Petroleum, 'About Pearl Petroleum'<https://www.pearlpetroleum.com> accessed 6 August 2019.

${ }^{116}$ Dana Gas, ' Kurdistan Region of Iraq' < http://www.danagas.com/en-us/operations/iraq> accessed 6 August 2019; MOL Group, 'Kurdistan'<https://molgroup.info/en/our-business/exploration-and-production/kurdistan> accessed 9 July 2019. Crescent Petroleum, 'Kurdistan Region of Iraq' < https://www.crescentpetroleum.com/2016/12/28/kurdistan-region-of-iraq2/> accessed 11 July 2019.

${ }^{117}$ Fathallah, op. cit., p. 100.

118 The Oil and Gas Year, The Oil and Gas Year: Kurdistan Region of Iraq 2009, loc. cit.

${ }^{119}$ Pearl Petroleum, loc. cit.

${ }^{120}$ Dana Gas, loc. cit.; MOL Group, loc. cit.; Crescent Petroleum, 'loc. cit.

${ }^{121}$ The Oil and Gas Year, The Oil and Gas Year: Kurdistan Region of Iraq 2014, op. cit., p. 48-49.

${ }^{122}$ Repsol, loc. cit. 


\subsubsection{Ber Bahr, Barda Rash and Chia Surkh Blocks:}

Ber Bahr block is located in north of Dohuk city and is 208 square kilometres. ${ }^{123}$ the block's estimated oil is more than 1.9 billion barrels of oil. ${ }^{124}$ The block was operated by Genel Energy with $40 \%$ interest, Gulf Keystone with $40 \%$ and KRG BI.20\% fully carried. ${ }^{125}$ However, Genel Energy and its partner formally relinquished in this block ${ }^{126}$ and currently it is a relinquished block. ${ }^{127}$ In terms of Barda Rash,this block is located in north west of Erbil city and covers Barda Rash district. The block's area is about 265 square kilometres ${ }^{128}$ and has an estimated 1.47 billion barrels of oil reserves. ${ }^{129} 60 \%$ of the stake was granted to Afren Company, $20 \%$ to Komet Group and $20 \%$ KRG BI.20\% fully carried. ${ }^{130}$ However, companies pulled out of the block and currently it is a relinquished block. ${ }^{131}$ Additionally, Chia Surkh block is located in southern Kurdistan Region, at the border with Iran, east of Sirwan river and covers Quratu and Maydan sub-districts in Khanaqin district. The block is 985 square kilometres ${ }^{132}$ and it was estimated that Chia Surkh block has 5.656 billion barrels of oil. ${ }^{133}$ The block is operating by Petoil with $80 \%{ }^{134}$ (after buying $20 \%$ and $40 \%$ of Genel Energy's stake in 2016 and 2017 respectively) ${ }^{135}$ and KRG BI.20\% fully carried. ${ }^{136}$

\subsubsection{Sheikh Adi,Khalakan and Taza Blocks:}

Sheikh Adi block is situated in east of Dohuk city, north of Shaikan district and is about 180 square kilometres. ${ }^{137}$ It is estimated to have 1.9 billion barrels of oil. ${ }^{138}$ The operators of the Sheikh Adi block were Gulf Keyston with $80 \%$ working interest and KRG BI.20\% fully carried. ${ }^{139}$ However, Gulf Keystoncompany relinquished the Sheikh Adi block ${ }^{140}$ and currently it is a relinquished block. ${ }^{141}$ Other block is Khalakan block which contains Khalakan town, Haibat Sultan mountain and a part of Koya district. The block's area is approximately 624 square kilometres. The block estimated to have 2.450 billion barrels of oil reserves. ${ }^{142}$ Participation of companies and their stake are as follows: Gas Plus Khalakan Ltd. $80 \%$ and KRG BI.20\% fully carried. ${ }^{143}$ Additionally, Taza block covers a part of Nawjul subdistrict and west of Qadr Karam sub-district. The block is 511 square kilometres. ${ }^{144}$ It is expected to have more than 3 billion barrels of oil reserves and enormous amount of gas reserves. ${ }^{145} 60 \%$ of the working interest was awarded to the Oil Search (an Australian company), 20\% to Total (a French company) and KRG BI.20\% fully carried. ${ }^{146}$

\footnotetext{
${ }^{123}$ The Oil and Gas Year, The Oil and Gas Year: Kurdistan Region of Iraq 2014, loc. cit.

${ }^{124}$ Fathallah, op. cit., p. 85.

${ }^{125}$ The Oil and Gas Year, The Oil and Gas Year: Kurdistan Region of Iraq 2013, loc. cit.; The Oil and Gas Year, The Oil and Gas Year: Kurdistan Region of Iraq 2014, op. cit., p. 42

${ }^{126}$ Genel Energy, 'Trading and operations update: 24 January 2017', loc. cit.

${ }^{127}$ Iraq Databank, loc. cit.

${ }^{128}$ The Oil and Gas Year, The Oil and Gas Year: Kurdistan Region of Iraq 2011, loc. cit.

${ }^{129}$ The Oil and Gas Year, The Oil and Gas Year: Kurdistan Region of Iraq 2013, op. cit., p. 83.

${ }^{130}$ The Oil and Gas Year, The Oil and Gas Year: Kurdistan Region of Iraq 2013, loc. cit.

${ }^{131}$ Iraq Databank, loc. cit.

${ }^{132}$ The Oil and Gas Year, The Oil and Gas Year: Kurdistan Region of Iraq 2014, op. cit., p. 48-49.

${ }^{133}$ Fathallah, op. cit., p. 104.

${ }^{134}$ Petoil, 'History' < http://www.petoil.com.tr/en/briefhistory.html> accessed 11 July 2019.

${ }^{135}$ Genel Energy, 'Trading and operations update: 20 January 2016' [Report]

<https://www.genelenergy.com/media/1888/genel-trading-and-operations-update-200116-final.pdf> accessed 7 August 2019; Genel Energy, 'Trading and operations update: 24 January 2017', loc. cit.

${ }^{136}$ The Oil and Gas Year, The Oil and Gas Year: Kurdistan Region of Iraq 2013, op. cit., p. 64-65; The Oil and Gas Year, The Oil and Gas Year: Kurdistan Region of Iraq 2014, op. cit., p. 42.

${ }^{137}$ The Oil and Gas Year, The Oil and Gas Year: Kurdistan Region of Iraq 2011, loc. cit.

${ }^{138}$ Fathallah, op. cit., p. 82.

${ }^{139}$ The Oil and Gas Year, The Oil and Gas Year: Kurdistan Region of Iraq 2013, loc. cit.; The Oil and Gas Year, The Oil and Gas Year: Kurdistan Region of Iraq 2014, loc. cit.

${ }^{140}$ Gulf Keystone Petroleum Ltd., 'Half Year Report for the Six Months Ended 30 June 2016' [Report]

<https://www.gulfkeystone.com/media/108120/2016-09-22-2016-Half-Year-Report.pdf> accessed 7 August 2019.

${ }^{141}$ Iraq Databank, loc. cit.

${ }^{142}$ Fathallah, op. cit., p. 97.

${ }^{143}$ NewAge, 'Kurdistan' < http://www.newafricanglobalenergy.com/kurdistan/> accessed 4 August 2019.

${ }^{144}$ The Oil and Gas Year, The Oil and Gas Year: Kurdistan Region of Iraq 2014, op. cit., p. 48-49.

${ }^{145}$ Fathallah, op. cit., p. 102.

${ }^{146}$ The Oil and Gas Year, The Oil and Gas Year: Kurdistan Region of Iraq 2014, op. cit., p. 42.
} 
However, in 2016, Oil Search company made decision to relinquish its interest in Taza block and withdrew from the Kurdistan due to disappointing results from its appraisal drilling program and the block was relinquished. ${ }^{147}$

2.4.3 Qush Tappa, Al Qush and Baranan Blocks:

Qush Tappa block begins from Qush Tappa, the bottom of Erbil city to Dobz and Perdi. The block is about 1180 square kilometres. ${ }^{148}$ At first, $80 \%$ of its stake was awarded to KNOC and $20 \%$ participation interest was hold by KRG but was carried fully by KNOC. ${ }^{149}$ However, the company withdrew from Qush Tappa block as it failed to discover oil there ${ }^{150}$ and according to the 'The Oil \& Gas Year: Kurdistan Region of Iraq 2016', this block is an open licence block. ${ }^{151}$ In terms of Al Qush,this block is located in North west of Kurdistan, the south of Dohuk city and its area is 306 square kilometres. ${ }^{152} \mathrm{Al}$ Qush block is granted to ExxonMobil with $80 \%$ of stake and KRG BI.20\% fully carried. ${ }^{153}$ Also, Baranan block covers south east of Sulaymaniyah city and Baranan mountain to Darbandikhan lake and is 722 square kilometres. ${ }^{154}$ The block was operated by Total (60\%), Murphy (20\%) and KRG BI.20\% fully carried. ${ }^{155}$ However, the companies relinquished their interests in Baranan block and currently it is a relinquished block. ${ }^{156}$

\subsubsection{Pulkhana, Sangaw South and Qara Dagh Block:}

Pulkhana Area contains Tuz Khurmatu district, Jabar sub-district and east of Tuz Khurmatu. ${ }^{157}$ Pulkhana block is approximately 529 square kilometres ${ }^{158}$ and it is estimated to have about 1.58 billion barrels of oil reserves. ${ }^{159}$ The block is awarded to Turkish Energy Company (TEC) (40\%), KRG BI.20\% fully carried and 40\% net third party interest. ${ }^{160}$ Moreover, Sangaw South block is located in south east of Kurdistan Region, Sangaw sub-district and its around. It is about 354 square kilometres ${ }^{161}$ and is estimated to have about 2 billion barrels of oil reserves; the block contains $1 \mathrm{tcm}$ gas. ${ }^{162}$ The operators of the block were: KNOC (30\%), KRG BI.20\% fully carried and $50 \%$ net third party interest up to $2014,{ }^{163}$

\footnotetext{
${ }^{147}$ Oil Search, 'Oil Search-Performance: 2016 Social Responsibility Report' [Report] <https://www.oilsearch.com/_data/assets/pdf_file/0020/19721/Oil-Search-Performance-2016.pdf> accessed 7 August 2019; Oil Search, 'The Power of Partnership: Annual Report 2016' [Report]

<http://www.annualreports.com/HostedData/AnnualReportArchive/O/ASX_OSH_2016.pdf

$>$ accessed 7 August 2019.

${ }^{148}$ Fathallah, op. cit., p. 99.

${ }^{149}$ The Oil and Gas Year, The Oil and Gas Year: Kurdistan Region of Iraq 2009, op. cit., p. 124.

${ }^{150}$ J Ji-hye, 'Korean Lawmaker Lowers Kurdistan Oil Prospects' < https://ekurd.net/korean-lawmaker-lowers-kurdistan-oilprospects-2015-03-19> accessed 8 August 2019.

${ }^{151}$ The Oil and Gas Year, The Oil and Gas Year: Kurdistan Region of Iraq 2016, loc. cit.

${ }^{152}$ The Oil and Gas Year, The Oil and Gas Year: Kurdistan Region of Iraq 2014, op. cit., p. 48-49.

${ }^{153}$ The Oil and Gas Year, The Oil and Gas Year: Kurdistan Region of Iraq 2014, op. cit., p. 42; Iraqi Oil Report, 'Exxon Cuts Kurdistan Portfolio by Half' < https://www.iraqoilreport.com/news/exxon-cuts-kurdistan-portfolio-half-

20566/?utm_source=IOR\%20Newsletter> accessed 8 August 2019.

${ }^{154}$ The Oil and Gas Year, The Oil and Gas Year: Kurdistan Region of Iraq 2014, op. cit., p. 48-49; Fathallah, op. cit., p. 95.

${ }^{155}$ The Oil and Gas Year, The Oil and Gas Year: Kurdistan Region of Iraq 2013, loc. cit.; The Oil and Gas Year, The Oil and Gas Year: Kurdistan Region of Iraq 2014, op. cit., p. 42.

${ }^{156}$ Iraq Databank, loc. cit. and Mees, 'Russian Companies' Expanded Presence'

<https://www.mees.com/2017/6/16/geopolitical-risk/russian-companies-expanded-presence/45609a30-54c2-11e7-bf6a-

3b2e0e15a20a> accessed 8 August 2019.

${ }^{157}$ Fathallah, op. cit., p. 103.

${ }^{158}$ The Oil and Gas Year, The Oil and Gas Year: Kurdistan Region of Iraq 2011, op. cit., p. 61;The Oil and Gas Year, The Oil and Gas Year: Kurdistan Region of Iraq 2014, op. cit., p. 48-49.

${ }^{159}$ Fathallah, loc. cit.

${ }^{160}$ The Oil and Gas Year, The Oil and Gas Year: Kurdistan Region of Iraq 2016, loc. cit.; Reuters, Iraqi Kurdistan Gives Turkish Company Six Oil Exploration Blocks'<https://www.reuters.com/article/turkey-kurdistan-oil/iraqi-kurdistan-givesturkish-company-six-oil-exploration-blocks-idUSL5N0EU44120130618> accessed 8 August 2019.

${ }^{161}$ The Oil and Gas Year, The Oil and Gas Year: Kurdistan Region of Iraq 2013, loc. cit.; The Oil and Gas Year, The Oil and Gas Year: Kurdistan Region of Iraq 2014, loc. cit.

${ }^{162}$ Fathallah, op. cit., p. 102.

${ }^{163}$ The Oil and Gas Year, The Oil and Gas Year: Kurdistan Region of Iraq 2014, op. cit., p. 42. 
However, KNOC withdrew from the Sangaw South oil field project in $2016^{164}$ and it is now a relinquished block. Last block that is contracted in this phase is Qara Dagh block; the block is located in Sulaymaniyeh city and covers Qara Dagh area, east of Sagrma mountain, west of Sirwan river to Darbandikhan. ${ }^{165}$ It is about 846 square kilometres ${ }^{166}$ and is estimated to contain 4.896 billion barrels of oil which is more than Egypt's oil reserves. ${ }^{167}$ Chevron with $40 \%$ interest, ${ }^{168}$ Genel Energy with $40 \%{ }^{169}$ and KRG with BI.20\% fully carried, are operators of the block. ${ }^{170}$

\subsection{The Latest Wave After Regional Oil and Gas Law:}

At this wave, KRG granted almost all remaining blocks in Erbil,Sulymaniah and Dohuk governorates to IOCs. Figure 2.6 shows the remaining blocks which are Sulevani, Central Dohuk, Dinarta, Shakrok, Arbat, Arbat East, Qara Hanjeer, Betwata, Pirmam, Halabja, Harir, Safeen, Piramagrun, Qala Dze, Choman, Hindren, Jabal Kand,Khurmala Dome, Baeshiqa and Guwayer blocks.

Figure 2.6: Granted Blocks in The Latest Wave After Regional Oil and Gas Law

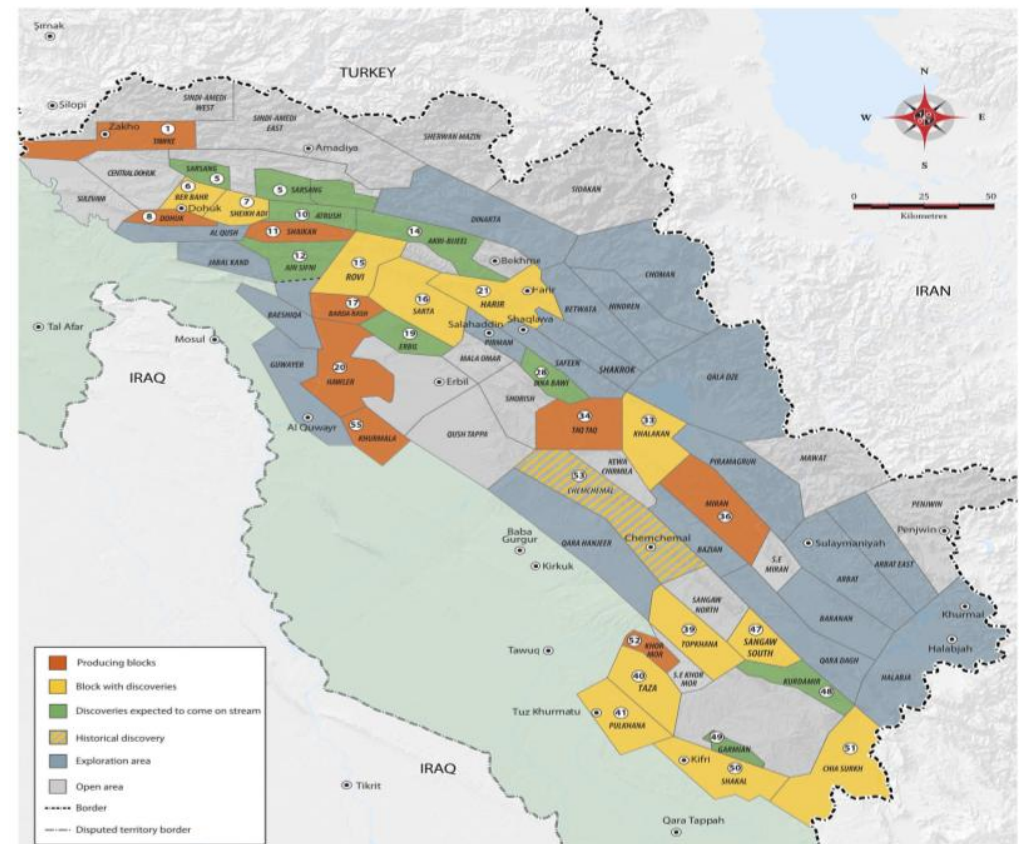

Source: The Oil and Gas Year, The Oil and Gas Year: Kurdistan Region of Iraq 2014(Wildcat International FZ-LLC, 2014) p. 48-49.

\subsubsection{Sulevani and Central Dohuk Blocks:}

Sulevani block covers below part of Zakho district to Mosul lake and is 700 square kilometres. ${ }^{171}$ In 2013, Sulevani block was operated by Petroquest Energy which owned $80 \%$ of block's stake and KRG BI.20\% fully carried. ${ }^{172}$ Also, Central Dohuk block contains north and central of Dohuk city. This block is 619 square kilometres. ${ }^{173}$

\footnotetext{
${ }^{164} \mathrm{~J}$ Min-hee, 'KNOC Pulls Out of Iraq's Sangaw Soth Oil Field Project'

<http://www.businesskorea.co.kr/news/articleView.html?idxno=15631> accessed 5 August 2019 and J Lee, 'KNOC drops Sangaw South Project' < https://www.iraq-businessnews.com/2016/09/05/knoc-drops-sangaw-south-project/> accessed 5 August 2019.

${ }^{165}$ Fathallah, op. cit., p. 105.

${ }^{166}$ The Oil and Gas Year, The Oil and Gas Year: Kurdistan Region of Iraq 2014, op. cit., p. 48-49.

${ }^{167}$ Fathallah, loc. cit.

${ }^{168}$ Chevron, loc. cit.

${ }^{169}$ Genel Energy, 'Qara Dagh'< https://www.genelenergy.com/operations/exploration-and-appraisal-assets/qaradagh/>accessed 4 August 2019.

${ }^{170}$ The Oil and Gas Year, The Oil and Gas Year: Kurdistan Region of Iraq 2013, loc. cit.; The Oil and Gas Year, The Oil and Gas Year: Kurdistan Region of Iraq 2014, op. cit., p. 42.

${ }^{171}$ Fathallah, op. cit., p. 82.

172 The Oil and Gas Year, The Oil and Gas Year: Kurdistan Region of Iraq 2013, loc. cit.

${ }^{173}$ The Oil and Gas Year, The Oil and Gas Year: Kurdistan Region of Iraq 2011, op. cit., p. 86.
} 
In 2013, the operators of this blocks were Murphy Oil (50\% of stake), Petroquest Energy (30\% of stake) and KRG (BI.20\% fully carried). ${ }^{174}$ However, according to the 'The Oil \& Gas Year: Kurdistan Region of Iraq 2014', these blocks were an open licence blocks in $2014^{175}$ and according to the 'The Oil \& Gas Year: Kurdistan Region of Iraq 2016 ' both blocks have been merged as an open licence block that named block 8 as shown in Figure 2.7. ${ }^{176}$

2.5.2 Dinarta, Shakrok and ArbatBlocks:

Dinarta blocks covers Mergasur district and Barzan area as well as a part of Akri and Sheladze. The block is about 1139 square kilometres. ${ }^{177}$ Also, Shakrok block starts from Khidran sub-distrect in Dukan district till nearby Shaqlawa district and is approximately 418 square kilometres. ${ }^{178} 64 \%$ of the working interest of each Dinarta and Shakrok blocks was awarded to Hess Oil Company, $16 \%$ to Petroceltic company and KRG BI.20\% fully carried. ${ }^{179}$ However, the companies have pulled out of the two blocks in 2015 and $2014 ;{ }^{180}$ currently both blocks are relinquished blocks. ${ }^{181}$ In terms of Arbat block,it contains Sulaymaniyah city, Goyzha and Azmr Mountains as well as Arbat sub-district to the New Halabja. The Arbat block is 974 square kilometres and the block is estimated to have 1.177 billion barrels of oil. ${ }^{182}$ This block is currently being operated by Turkish Energy Company (TEC) (80\%) and KRG BI.20\% fully carried. ${ }^{183}$

\subsubsection{Arbat East, Qara Hanjeer, Betwata andPirmam Blocks:}

Arbat Eastblock covers Siwail and Barznja areas, a part of Sharazur to Nalparez sub-district in Penjwin district and is 700 square kilometres. ${ }^{184}$ Qara Hanjeer block is located between Chemchemal district and Kirkuk city and is 10 kilometres away from Kirkuk city. Qara Hanjear block covers Shwan area, Qara Hanjeer sub-district and Takey Jabari sub-district. ${ }^{185}$ The block is 1235 square kilometres ${ }^{186}$ and is estimated to has 5-10billion barrels of oil. ${ }^{187}$ Also, Betwata block starts from Hajiawa to Betwata town, Balisan and Khoshnawati area. The block is about 589 square kilometres. ${ }^{188} 80 \%$ of the working interest of the each mentioned three blocks was awarded to ExxonMobil (an Amarican company) and KRG BI.20\% fully carried. ${ }^{189}$ However, ExxonMobil has pulled out and relinquished the three blocksand they are currently relinquished blocks. ${ }^{190}$ Dr. Ashti Hawrami on the sidelines of a conference in London said "[s]ome companies didn't meet contractual deadlines and according to the contract had to relinquish their areas," ${ }^{191} \mathrm{He}$ means ExxonMobil had pulled out of the Arbat East, Betwata and Qara Hanjeer blocks because it could not fulfill its contract with the region's government.

\footnotetext{
174 The Oil and Gas Year, The Oil and Gas Year: Kurdistan Region of Iraq 2013, loc. cit.

175 The Oil and Gas Year, The Oil and Gas Year: Kurdistan Region of Iraq 2014, loc. cit.

${ }^{176}$ The Oil and Gas Year, The Oil and Gas Year: Kurdistan Region of Iraq 2016, loc. cit.

${ }^{177}$ Fathallah, op. cit., p. 83; The Oil and Gas Year, The Oil and Gas Year: Kurdistan Region of Iraq 2014, op. cit.,p. 48-49.

178 The Oil and Gas Year, The Oil and Gas Year: Kurdistan Region of Iraq 2014, loc. cit.; Fathallah, op. cit., p.106.

179 The Oil and Gas Year, The Oil and Gas Year: Kurdistan Region of Iraq 2013, loc. cit. and The Oil and Gas Year, The Oil and Gas Year: Kurdistan Region of Iraq 2014, op. cit., p. 42.

${ }^{180}$ Irish Examiner Ltd, 'Petroceltic Pulls Out of Kurdistan'<https://www.irishexaminer.com/business/petroceltic-pulls-outof-kurdistan-320519.html> accessed 5 August 2019.

${ }^{181}$ Iraq Databank, loc. cit.

182 Fathallah, op. cit., p. 96.

183 The Oil and Gas Year, The Oil and Gas Year: Kurdistan Region of Iraq 2016, loc. cit.; Reuters, loc. cit.

${ }^{184}$ Fathallah, loc. cit.

${ }^{185}$ Fathallah, op. cit., p. 102-103.

${ }^{186}$ The Oil and Gas Year, The Oil and Gas Year: Kurdistan Region of Iraq 2014, op. cit., p. 48-49.

${ }^{187}$ Fathallah, loc. cit.

${ }^{188}$ The Oil and Gas Year, The Oil and Gas Year: Kurdistan Region of Iraq 2014, loc. cit.

${ }^{189}$ The Oil and Gas Year, The Oil and Gas Year: Kurdistan Region of Iraq 2013, loc. cit.; The Oil and Gas Year, The Oil and Gas Year: Kurdistan Region of Iraq 2014, op. cit., p. 42.

${ }^{190}$ Iraq Databank, loc. cit.; The Oil \& Gas Year, 'ExxonMobil Exits Kurdistan Region Blocks'

<https://www.theoilandgasyear.com/news/exxonmobil-exits-kurdistan-region-blocks/> accessed 8 August 2019; Upstream

Online, 'ExxonMobil Leaves blocks' < https:/www.upstreamonline.com/hardcopy/1197633/exxonmobil-leaves-blocks>

accessed 8 August 2019; D Abdullah, 'ExxonMobil Pulled Out of Kurdistan: Because of Iranian Influence'

<https://www.iraq-businessnews.com/2017/01/05/exxonmobil-pulled-out-of-kurdistan-because-of-iranian-

influence/>accessed 8 August 2019.

${ }^{191}$ A Hawrami cited in The Oil and Gas Year, 'ExxonMobil Exits Kurdistan Region Blocks' loc. cit. 
On the other hand, Pirmam blockcontains central of Pirmam sub-district, Sari Rash and Sarban. Pirmam block is approximately 211 square kilometres. ${ }^{192}$ The block is operated by ExxonMobil which holds $80 \%$ of block's stake and KRG BI.20\% fully carried. ${ }^{193}$

\subsubsection{Halabja Block:}

Halabja block is located in the border of Halabja city and contains Khurmal, Sirwan, Biyara and Glejal sub-districts as well as central of Halabja and a part of Said Sadiq. Its area is approximately 1000square kilometres. ${ }^{194}$ The block is estimated to have 630 million to 790 million barrels of oil. ${ }^{195}$ Gazprom Neft with $80 \%$ of stake and KRG BI.20\% fully carried were operating the block. ${ }^{196}$ However, in 2017, Gazprom Neft decided not to develop and quit the Halabja block and the company's arguments to reject drilling on the block were well justified and relinquished in September 2017..$^{197}$

\subsubsection{Harirand Safeen Blocks:}

Harir block covers Harir sub-district, north of Shaqlawa, to Soran district. Harir block is about 700square kilometres. It is estimated to have 1 billion barrels of oil. ${ }^{198}$ The block was operated by Marathon Oil with $45 \%$ of stake, ${ }^{199}$ the French company, Total, with 35\% and KRG BI. (20\%) fully carried. ${ }^{200}$ However, in 2016, the block was relinquished to the $\mathrm{KRG}^{201}$ and currently is a relinquished block. ${ }^{202}$ Also, Safeen block covers on the tope of Safeen mountain to Hezop and is 424 square kilometres. ${ }^{203}$ The operators of the block were: Total with $80 \%$ working interest and KRG BI. (20\%) fully carried. ${ }^{204}$ However, it is currently a relinquished block. ${ }^{205}$

\subsubsection{Piramagrun and Qala Dze Blocks:}

Piramagrun block covers east of Dukan-Sulaymaniyah highway, the foot of Piramagrun mountain to Dukan district ${ }^{206}$ and is more than 680 square kilometres. ${ }^{207}$ Also, Qala Dze (Qaladze) block contains all Qaladze district, Bari Marga, Dukan lake and Raniya. ${ }^{208}$ It is about 1882 square kilometres. ${ }^{209}$

${ }^{192}$ The Oil and Gas Year, The Oil and Gas Year: Kurdistan Region of Iraq 2014, op. cit., p. 48-49.

${ }^{193}$ The Oil and Gas Year, The Oil and Gas Year: Kurdistan Region of Iraq 2013, loc. cit.; The Oil and Gas Year, The Oil and Gas Year: Kurdistan Region of Iraq 2014, op. cit., p. 42; The Oil \& Gas Year, 'ExxonMobil Exits Kurdistan Region Blocks', loc. cit.

${ }^{194}$ Fathallah, op. cit., p. 106.

${ }^{195}$ The Oil and Gas Year, The Oil and Gas Year: Kurdistan Region of Iraq 2014, op. cit., p. 72.

${ }^{196}$ The Oil and Gas Year, The Oil and Gas Year: Kurdistan Region of Iraq 2014, op. cit., p. 42; The Oil and Gas Year, The Oil and Gas Year: Kurdistan Region of Iraq 2016, loc. cit.; Gazprom Neft, 'Iraq'

<http://www.gazprom.com/about/production/projects/deposits/iraq/?from=rss> accessed 9 August 2019.

${ }^{197}$ Gazprom Neft, 'Oil-rim Deposits Account for 15 to 20 Percent of Production at Gazprom Neft -and Their Contribution is Expected to Increase' <https://www.gazprom-neft.com/press-center/lib/2677288/>accessed 9 August 2019, Gazprom Neft, 'Gazprom Neft Sees Good Prospects in Kurdistan' <https://www.gazprom-neft.com/press-center/lib/1159674/> accessed 9 August 2019.

${ }^{198}$ Fathallah, op. cit., p. 99.

${ }^{199}$ Marathon Oil Corporation, 'Annual Report Pursuant to Section 13 Or 15(D) of The Securities Exchange Act of 1934 For the Fiscal Year Ended December 31, 2015' [Report]

<https://www.marathonoil.com/content/documents/Investors/Annual_Reports_and_Proxy/annual_report_2015.pdf > accessed 11 July 2019.

${ }^{200}$ The Oil and Gas Year, The Oil and Gas Year: Kurdistan Region of Iraq 2013, loc. cit.; The Oil and Gas Year, The Oil and Gas Year: Kurdistan Region of Iraq 2014.

${ }^{201}$ Marathon Oil Corporation, 'Annual Report Pursuant to Section 13 Or 15(D) of The Securities Exchange Act of 1934 For the Fiscal Year Ended December 31, 2017' [Report]

<https://www.marathonoil.com/content/documents/Investors/Annual_Reports_and_Proxy/2017AnnualReport.pdf> accessed 9 August 2019.

${ }^{202}$ The Oil and Gas Year, The Oil and Gas Year: Kurdistan Region of Iraq 2016, loc. cit.; Iraq Databank, loc. cit.

${ }^{203}$ The Oil and Gas Year, The Oil and Gas Year: Kurdistan Region of Iraq 2014, op. cit., p. 48-49.

${ }^{204}$ ibid., p. 42.

205 The Oil and Gas Year, The Oil and Gas Year: Kurdistan Region of Iraq 2016, loc. cit.; Iraq Databank, loc. cit.

${ }^{206}$ Fathallah, op. cit., p.105.

${ }^{207}$ The Oil and Gas Year, The Oil and Gas Year: Kurdistan Region of Iraq 2014, op. cit., p. 48-49.

${ }^{208}$ Fathallah, loc. cit.

${ }^{209}$ The Oil and Gas Year, The Oil and Gas Year: Kurdistan Region of Iraq 2014, loc. cit. 
Each block was operated by Repsol company which holds $40 \%$ of stake, Maersk Oil with $40 \%$ and KRG BI.20\% fully carried. ${ }^{210}$ However, companieswithdrew from both blocks and currently they are relinquished block. ${ }^{211}$

\subsubsection{Choman, Hindren and Jabal Kand Blocks:}

Choman block and Hindren blockare located in Erbil city. Each of these blocks was operated by Turkish Energy Company (TEC) with $80 \%$ stake and KRG BI.20\% fully carried. ${ }^{212}$ However, the company withdrew from the two blocks and they arecurrentlyrelinquished blocks. ${ }^{213}$ Besides,Jabal Kand block covers north east of Mosul city and is about 400 square kilometres. ${ }^{214}$ This block is being operated by Turkish Energy Company (TEC) (40\%), KRG BI.20\% fully carriedand $40 \%$ net third party interest. ${ }^{215}$

2.5.8 Khurmala,Baeshiqa and Guwayer Blocks:

Khurmala block is located in Erbil city and contains both areas of Khurmala and Avana of Khurmala. ${ }^{216} 100 \%$ of Khurmala Dome block's stake belongs to a Kurdish company which is Kar Group. ${ }^{217}$ Also, Baeshiqa block is in Baeshiqa town that is located in east of Mosul cityand is approximately 318 square kilometres. ${ }^{218}$ The block is being operated by ExxonMobil with 32\%, DNO with 32\%, The Turkish Energy Company (TEC) with 16\% working interest and KRG with $20 \%$ fully carried interest. ${ }^{219}$ Another granted block was Guwayer (Gwer). Guwayer block is added to Kurdistan oil and gas blocks in 2014. This block is located in Guwayer. The operators of this block are Komet Group with $80 \%$ working interest and the KRG BI $20 \%{ }^{220}$

Moreover, despite the mentioned blocks, there are a number of blocks that are still open which are Penjwin and S.E Khor Mor as well as Sherwan Mazin, Sidakan and Mawat as seen Figure 2.6.However, it can be mentioned that according to the latest map of 'The Kurdistan Oil \& Gas Year: Kurdistan Region of Iraq 2016', as illustrated in Figure 2.7, the size and number of Kurdistan exploration and production blocks have been redesigned again.Figure 2.7 shows current situation of Kurdistan blocks.

\footnotetext{
210 ibid., p. 42.

${ }^{211}$ The Oil and Gas Year, The Oil and Gas Year: Kurdistan Region of Iraq 2016, loc. cit.; Iraq Databank, loc. cit.; Mees, 'Firms Back out of KRG Assets' <https://www.mees.com/2015/12/4/oil-gas/firms-back-out-of-krg-assets/e3327410-493211e7-b9b5-71ae6bc67ab1> accessed 9 August 2019.

212 The Oil and Gas Year, The Oil and Gas Year: Kurdistan Region of Iraq 2013, loc. cit.; The Oil and Gas Year, The Oil and Gas Year: Kurdistan Region of Iraq 2014, loc. cit.

${ }^{213}$ Iraq Databank, loc. cit.; Shadow Governance Intel, 'Turkey Expands Influence in Kurdish Energy Sector' <https://oilprice.com/Energy/Oil-Prices/Turkey-Expands-Influence-In-Kurdish-Energy-Sector.html\#> accessed 8 August 2019.

${ }^{214}$ Fathallah, op. cit., p.85.

215 The Oil and Gas Year, The Oil and Gas Year: Kurdistan Region of Iraq 2016, loc. cit.; Reuters, loc. cit.

${ }^{216}$ Fathallah, op. cit., p. 98.

217 The Oil and Gas Year, The Oil and Gas Year: Kurdistan Region of Iraq 2014, op. cit., p. 42; The Oil and Gas Year, The Oil and Gas Year: Kurdistan Region of Iraq 2016, loc. cit.

218 The Oil and Gas Year, The Oil and Gas Year: Kurdistan Region of Iraq 2014, op. cit., p. 48-49.

${ }^{219}$ DNO, 'DNO Joins ExxonMobil on Baeshiqa License in Kurdistan; Assumes Operatorship' <https://www.dno.no/en/investor-relations/announcements/2017/dno-joins-exxonmobil-on-baeshiqa-license-in-kurdistanassumes-operatorship-/> accessed 4 August 2019; DNO, 'Kurdistan Region of Iraq', loc. cit.

${ }^{220}$ The Oil and Gas Year, The Oil and Gas Year: Kurdistan Region of Iraq 2014, op. cit., p. 42; The Oil and Gas Year, The Oil and Gas Year: Kurdistan Region of Iraq 2016, loc. cit.
} 
Figure 2.7: The Map of Kurdistan Exploration and Production Blocks in 2016

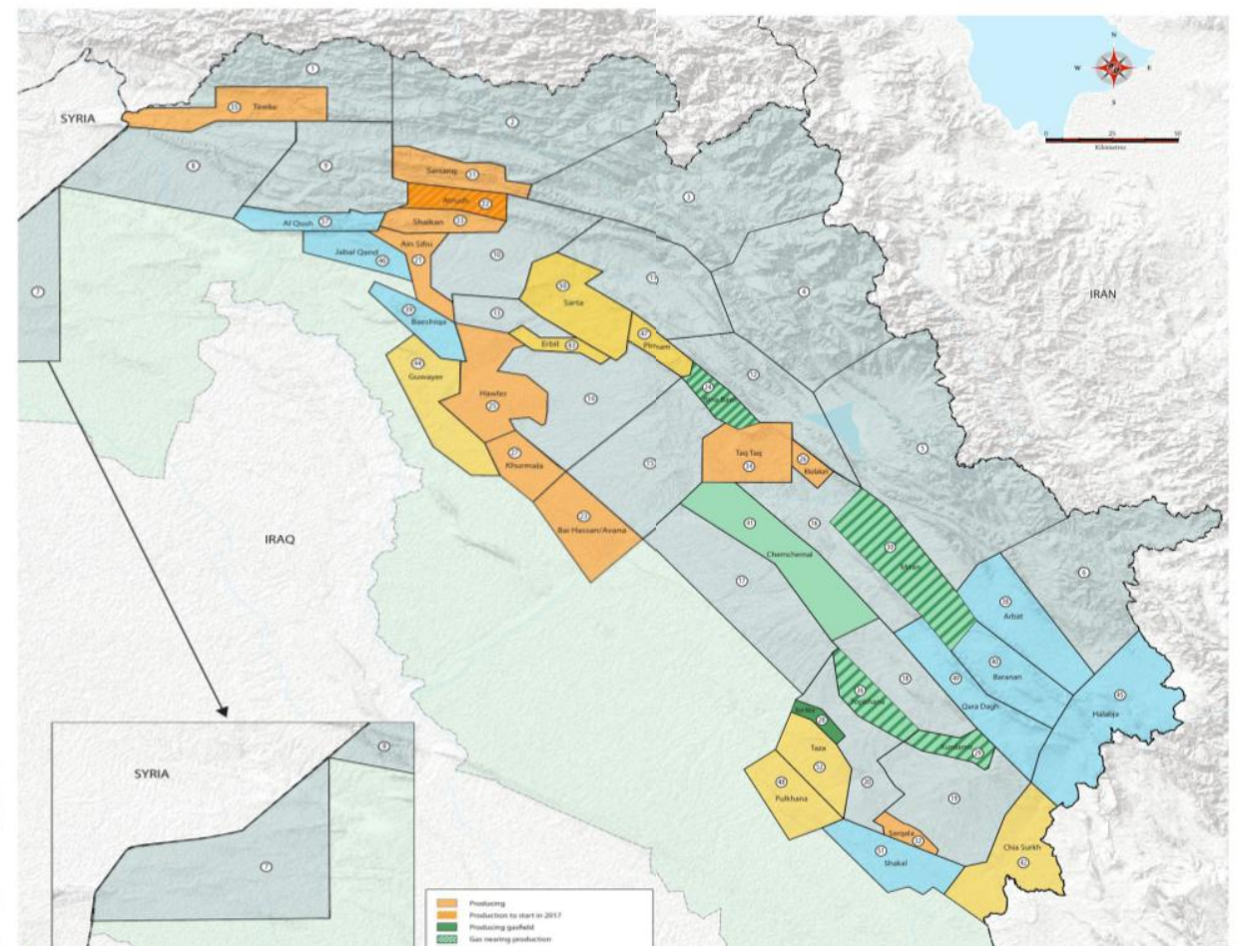

Source:The Oil and Gas Year, The Oil and Gas Year: Kurdistan Region of Iraq 2016(Wildcat International FZ-LLC, 2016) p. 31-32.

After clarifying all Kurdistan's oil and gas blocks as well as naming all invested International oil and gas companies in these blocks, it can be seenthat since 2014several companies have started to relinquishtheir interests in a total of 29 blocks (as mentioned in section 2.2). The relinquishment has happened due to a number of reasons. The most significant reasons are the beginning of the fight against the Islamic State of Iraq and Syria (ISIS)in Iraq, ${ }^{*}$ not meeting contractual deadlines by some companies, the dramatic mid-2014 fall in oil prices, disappointment in initial geological expectations andgeological complexity in some blocks, lack of infrastructureand to some extent, the KRG's difficulty to pay IOCs ${ }^{* *}$ working in Kurdistan until February 2016. The relinquishments weighed heavily on the KRG that already faces an economic crisis.

\footnotetext{
* In June 2014, following the withdrawal of Iraqi Army, the Islamic State of Iraq and Syria (ISIS) captured Mosul (the second largest city in Iraq). ISIS was a dangerous group that combined terrorist and traditional military tactics. In August of that year ISIS overran the city of Sinjar and threatened to attack Erbil. Sources: Y Abbas Zadeh and S Kirmanji, 'The ParaDiplomacy of the Kurdistan Region in Iraq and the Kurdistan Statehood Enterprise' (2017) 71(4) Middle East Journal 557606 and R Mills, Under the Mountains: Kurdish Oil and Regional Politics, OIES Paper: WPM 63 (Oxford Institute for Energy Studies, Oxford 2016) p. 17 <https://www.oxfordenergy.org/wpcms/wp-content/uploads/2016/02/Kurdish-Oil-andRegional-Politics-WPM-63.pdf >accessed 4 August 2019.

** Due to the history of petroleum conflict between the KRG and The Iraqi Government, the oil companies operating in Kurdistan irregularly received payments for the oil produced and exported from 2009 until 2015. In 2014 and February 2015, the KRG made some irregular payments to the main operating IOCs. Therefore, without regular payment, Investor confidence was damaged and the smaller companies were under considerable financial stress. From September 2015, the KRG attempted to regularise the payments. In February 2016, the KRG announced a new payment arrangement for IOCs based on PSC terms. 2016 was a more financially stable time for the IOCs with the monthly payments from MNR and higher oil prices.Sources: R Mills, A Rocky Roud: Kurdish Oil \& Independence, Paper Number: IEI190218 (Iraqi Energy Institute, Baghdad 2018) p.48 <https://iraqenergy.org/product/a-rocky-road-kurdish-oil-and-independence-report/>accessed 4 August 2019; A Tabaqchali, Statehood in the Kurdistan Region of Iraq Through an Economic Lens ( Institute of Regional and International Studies: American University of Iraq, Sulaimani 2018) p.9

<http://auis.edu.krd/iris/sites/default/files/Statehood\%20in\%20KRI\%20through\%20an\%20Economic\%20Lens_\%20FINAL.p df $>$ accessed 4 August 2019.
} 
Fortunately, despite leaving the region by several global companies, Rosneft (Russian national oil company) entered Kurdistan in February 2017 and signed an agreement with the KRG to cooperate in petroleum activities such as exploration, production, infrastructure, logistics and trading. ${ }^{221}$ The company and the KRG, on 18 October 2017, signed documents required for the enactment of Production sharing contracts for five blocks ${ }^{22}$ All five of which bear the names of towns in Kurdistan: Batil, Darato, Qasrok, Zawita and Harir-Bejil. The company holds $80 \%$ stake in all blocks with estimated of 670 million barrels of recoverable oil reserves. Also, Rosneft owns $60 \%$ share of crude pipeline infrastructure in Kurdistanand KAR Group, the current oil pipeline operatorwith $40 \%$ share is the other project participant. ${ }^{223}$ Additionally, in 2017, Sergei M. Petrov (General director of Gazprom Neft Middle East) in an interview with Nefte Compass, in answering the question: is Gazprom Neft considering other blocks in Kurdistan?" he revealed that "[w]e are ready to expand, to look at new blocks. Gazprom Neft is in constant negotiations on the issue with the regional natural resources ministry, which offered us some 10 blocks for consideration. Having studied the available

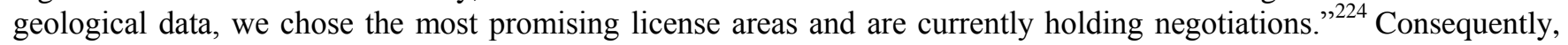
2017 has seen a dramatic shift in the Kurdistan Region's oil and gas prospects.

At the end of this paper, the study question will be answered. It is clear that oil and gas contracts are known for their longevity, the KRG's exploration and development contractshave been signed for 25 years and may last more than 37 years due to theextending right of contractors. ${ }^{225}$ Undoubtedly, by signed contracts for this extensive period and absenting of renegotiation clause, the KRG could not easily reform its oil and gas contracts for the mentioned period. However, from this study it can be clarified that several companies have currently relinquishedtheir blocks and KRG has about 24 open licence blocks with significant available data such as 2D or/and 3D seismic survey for and a number of existing wells in the most of these blocks. Therefore, it is a great opportunity for the KRG to reform its oil and gas contracts or to get rid of the complications of some clauses or articles in the contracts, even to change the type of contracts, before dealing with IOCs, which is the main aim of this thesis.

\section{Conclusion}

Since 2003, the Kurdistan Region has significantly developed, especially in oil and gas sector and has become internationally recognized as an extremely attractive petroleum region. This study has proved the KRG's new chance to reform its oil and gas contracts according to its new regional blocks divisions.

The studyillustrated geographical division of Kurdistan's blocks and their reserves. Kurdistan holds about 45 billion barrels of oil in reserves and 2.8-5.7 trillion cubic metres of estimated gas reserves. Kurdistan's energy structured domain consists of four main zones which are Taurus Mountains, Taurus Foothills, Zagros Foothills and Zagros Mountains zones.

The KRG is dependent on the block system for granting its oil and gas fields so has divided the four mentioned zones into several blocks. The number and size of these blocks have being redesigned several times. At the beginning, the KRG had 57 oil and gas blocks andhas made various contracts with IOCs in different phases. Before 2005, only 7 blocks granted to IOCs which were DNO, Petoil, Prime, Genel Energy, Addax Petroleum and Westeren Zagrose Ltd. Till 2013, more than 50 blocks were granted by the KRG andthere were only five open blocks. In 2014, the Kurdistan's blocks were redesignedand their number rose to 66 blocks withonly 16 open blocks. However, some of these block's operators are changed due to selling and acquiring of work interest by IOCs or relinquishing a part or entire blocks as clarified in this study.

Since 2014, some IOCs have begun to relinquish their work interests in 29 blocks due to a number of reasons such as the start of the fight against ISIS in Iraq, failure to meet contractual deadlines by some companies, the dramatic fall in oil prices in mid-2014, lack of IOCs capability and infrastructure, and the KRG's difficulty in paying IOCs working in Kurdistan until February 2016.

However, despite leavingof several IOCs, 2017 has seen a dramatic shift in the Kurdistan Region's oil and gas prospects.Rosneft entered Kurdistan in 2017 and signed a cooperation agreement with the KRG on petroleum activates. Consequently, the KRG granted 5 blocks to Rosneft with $80 \%$ working interest in each block.

\footnotetext{
${ }^{221}$ Rosneft, 'Q1 2017 Operating Results' <https://www.rosneft.com/press/releases/item/186405/> accessed 12 August 2019.

${ }^{222}$ Rosneft, 'Operating Results for Q3 and 9M 2017' <https://www.rosneft.com/press/releases/item/188603/> accessed 12 August 2019.

${ }^{223}$ V Katona, 'The Energy Giant Taking Over Kurdistan' < https://oilprice.com/Energy/Energy-General/The-Energy-GiantTaking-Over-Kurdistan.html> accessed 12 August 2019.

${ }^{224}$ Sergei M. Petrov interviewed by Nefte Compass cited in Gazprom Neft, 'Gazprom Neft Sees Good Prospects in Kurdistan' <https://www.gazprom-neft.com/press-center/lib/1159674/> accessed 12 August 2019.

${ }^{225}$ Salih and Salih, loc. cit.; also see Oil and Gas Law of the Kurdistan Region- Iraq No. (22) of 2007, Article 37 (First). 
On the other hand, GazpromNeft is in constant negotiations to obtain 10 blocks for consideration. At the end of this study, it is clear that the KRG would not easily reform its signed oil and gas contracts for the signed period, but this study has clarified that several IOCs have now abandoned their blocks. The KRG has about 24 open license blocks with significant data available and existing wells for most of them. Hence, it is a great opportunity for the KRG to reform its oil and gas contracts or to extricate the contracts from the complications of several clauses or articles, even to change the type of contracts, before dealing and signing new contracts with IOCs.

\section{References:}

\section{Books and Chapters from Edited Books:}

Auzer,K A,Institutional Design and Capacity to Enhance Effective Governance of Oil and Gas Wealth: The Case of Kurdistan Region (Springer Nature Singapore Pte Ltd: Gateway East, Singapore 2017).

Fathallah,S J,Kurdistan Region's Oil (in Kurdish) (Narin, Erbil 2015).

Owtram,F, 'The Federalization of Natural Resources' in A Danilovich (ed), Iraqi Federalism and the Kurds: Learning to Live Together (Ashgate Publishing Limited, Surrey 2014) PP.113-141.

Tabaqchali,A, Statehood in the Kurdistan Region of Iraq Through an Economic Lens (Institute of Regional and International Studies: American University of Iraq, Sulaimani 2018).

The Oil and Gas Year, The Oil and Gas Year: Kurdistan Region of Iraq 2009 (Wildcat Publishing Inc., Neuilly Seine 2009).

The Oil and Gas Year, The Oil and Gas Year: Kurdistan Region of Iraq 2011(Wildcat International FZ-LLC, Neuilly Seine 2011).

The Oil and Gas Year, The Oil and Gas Year: Kurdistan Region of Iraq 2013(Wildcat International FZ-LLC, Neuilly Seine 2013).

The Oil and Gas Year, The Oil and Gas Year: Kurdistan Region of Iraq 2014 (Wildcat International FZ-LLC, Neuilly Seine 2014).

The Oil and Gas Year, The Oil and Gas Year: Kurdistan Region of Iraq 2016 (Wildcat International FZ-LLC, Neuilly Seine 2016).

\section{The Kurdistan Regional Government's Official Websites:}

KRG, 'Statement on Oil \& Gas Policy by the Kurdistan Regional Government' <http://www.krg.org/a/d.aspx?l=12\&a=46337> accessed 12 June 2019.

Ministry of Natural Resources, 'Capacity Building Payments Received by KRG from All PSCs and Its Utilisation' <http://mnr.krg.org/images/pdfs/Production\%20Data\%20ENG\%20PDF.pdf> accessed 12 July 2019.

Ministry of Natural Resources, 'Structural Domain' <http://mnr.krg.org/index.php/en/structural-domain> accessed 20 June 2019.

\section{The International Oil Companies' Official Websites:}

Chevron, 'Iraq' < https://www.chevron.com/worldwide/iraq> accessed 4 August 2019.

Crescent Petroleum, 'Kurdistan Region of Iraq' <https://www.crescentpetroleum.com/2016/12/28/kurdistan-region-ofiraq-2/> accessed 11 July 2019.

Dana Gas, 'Kurdistan Region of Iraq' <http://www.danagas.com/en-us/operations/iraq> accessed 6 August 2019. MOL Group, 'Kurdistan' <https://molgroup.info/en/our-business/exploration-and-production/kurdistan> accessed 9 July 2019.

DNO, 'DNO Increases Tawke Stake; Announces Settlement of Kurdistan Receivables' $<$ https://www.dno.no/en/investor-relations/announcements/2017/dno-increases-tawke-stake-announcessettlement-of-kurdistan-receivables/> accessed 4 August 2019.

DNO, 'DNO Joins ExxonMobil on Baeshiqa License in Kurdistan; Assumes Operatorship' <https://www.dno.no/en/investor-relations/announcements/2017/dno-joins-exxonmobil-on-baeshiqa-licensein-kurdistan-assumes-operatorship-/> accessed 4 August 2019.

DNO, 'Kurdistan Region of Iraq' <https://www.dno.no/en/operations/where-we-operate/kurdistan1/> accessed 4 August 2019.

Gazprom Neft, 'Gazprom Neft Expands Oil Production in The Kurdistan Region of Iraq' < https://www.gazpromneft.com/press-center/news/2664279/> accessed 9 July 2019. 
Gazprom Neft, 'Gazprom Neft Sees Good Prospects in Kurdistan' < https://www.gazprom-neft.com/presscenter/lib/1159674/> accessed 9 August 2019.

Gazprom Neft, 'Iraq' <http://www.gazprom.com/about/production/projects/deposits/iraq/?from=rss> accessed 9 August 2019.

Gazprom Neft, 'Oil-rim Deposits Account for 15 to 20 Percent of Production at Gazprom Neft -and Their Contribution is Expected to Increase' <https://www.gazprom-neft.com/press-center/lib/2677288/>accessed 9 August 2019.

Genel Energy, 'Miran'< <ttps://www.genelenergy.com/operations/kri-development/miran/>accessed 4 August 2019.

Genel Energy, 'Qara Dagh'<https://www.genelenergy.com/operations/exploration-and-appraisal-assets/qaradagh/>accessed 4 August 2019.

Genel Energy, 'Snapshot of Genel Energy' < https://www.genelenergy.com/about-us/who-we-are/snapshot-of-genelenergy/>accessed 4 August 2019.

Genel Energy, 'Tawke - Peshkabir' <https://www.genelenergy.com/operations/kri-production/tawkepeshkabir/>accessed 4 August 2019.

Genel Energy, 'Trading and operations update: 20 January 2016' [Report] $<$ https://www.genelenergy.com/media/1888/genel-trading-and-operations-update-200116-final.pdf > accessed 7 August 2019.

Genel Energy, 'Trading and operations update: 24 January 2017' [Report] <https://www.genelenergy.com/media/2021/genel-trading-and-operations-update-jan-2017-final.pdf > accessed 7 August 2019.

Gulf Keystone Petroleum Ltd., 'Half Year Report for the Six Months Ended 30 June 2016' [Report] <https://www.gulfkeystone.com/media/108120/2016-09-22-2016-Half-Year-Report.pdf> accessed 7 August 2019.

Gulf Keystone Petroleum, 'Kurdistan Region of Iraq' <https://www.gulfkeystone.com/operations/shaikan'\%20and\%20'x'='x> accessed 4 August 2019.

HKN Energy Ltd., 'Financial Statements: December 31, 2018 and 2017' <https://www.hknenergy.com/wpcontent/uploads/2019/04/FY18_HKNEnergyLtd_FS-1.pdf> accessed 7 August 2019.

HKN Energy Ltd., 'Operations in The Kurdistan Region of Iraq' < https://www.hknenergy.com/operations/> accessed 7 August 2019.

Irish Examiner Ltd, 'Petroceltic Pulls Out of Kurdistan' <https://www.irishexaminer.com/business/petroceltic-pullsout-of-kurdistan-320519.html> accessed 5 August 2019.

KNOK, 'Iraq' <https://www.knoc.co.kr/ENG/sub03/sub03_1_5_1.jsp> accessed 9 July 2019.

Marathon Oil Corporation, 'Annual Report Pursuant to Section 13 Or 15(D) of The Securities Exchange Act of 1934 For the Fiscal Year Ended December 31, 2015'[Report]

<https://www.marathonoil.com/content/documents/Investors/Annual_Reports_and_Proxy/annual_report_2015 .pdf> accessed 11 July 2019.

Marathon Oil Corporation, 'Annual Report Pursuant to Section 13 Or 15(D) of The Securities Exchange Act of 1934 For the Fiscal Year Ended December 31, 2017'[Report] <https://www.marathonoil.com/content/documents/Investors/Annual_Reports_and_Proxy/2017AnnualReport. pdf $>$ accessed 9 August 2019.

Mees, 'Firms Back out of KRG Assets' <https://www.mees.com/2015/12/4/oil-gas/firms-back-out-of-krgassets/e3327410-4932-11e7-b9b5-71ae6bc67ab1> accessed 9 August 2019.

Mees, 'Russian Companies' Expanded Presence' <https://www.mees.com/2017/6/16/geopolitical-risk/russiancompanies-expanded-presence/45609a30-54c2-11e7-bf6a-3b2e0e15a20a> accessed 8 August 2019.

MOL Group, 'Kurdistan' <https://molgroup.info/en/our-business/exploration-and-production/kurdistan> accessed 4 August 2019.

MOL Group, Relinquishment of the Akri-Bijeel Block in the Kurdistan Region of Iraq' $<$ https://molgroup.info/en/investor-relations/investor-news/relinquishment-of-the-akri-bijeel-block-in-thekurdistan-region-of-iraq> accessed 5 August 2019.

NewAge, 'Kurdistan' <http://www.newafricanglobalenergy.com/kurdistan/> accessed 4 August 2019.

Oil Search, 'Oil Search-Performance: 2016 Social Responsibility Report' [Report] <https://www.oilsearch.com/_data/assets/pdf_file/0020/19721/Oil-Search-Performance-2016.pdf> accessed 7 August 2019.

Oil Search, 'The Power of Partnership: Annual Report 2016' [Report] $<$ http://www.annualreports.com/HostedData/AnnualReportArchive/O/ASX_OSH_2016.pdf

Oryx Petroleum, 'Kurdistan Region of Iraq' < https://www.oryxpetroleum.com/en/operations/iraq.php> accessed 9 July 2019. 
Pearl Petroleum, 'About Pearl Petroleum'<https://www.pearlpetroleum.com> accessed 6 August 2019.

Petoil, 'History'<http://www.petoil.com.tr/en/briefhistory.html> accessed 11 July 2019.

Repsol, 'Acquisation of Talisman Energy'

<https://www.repsol.com/imagenes/global/es/Acquisition_of_Talisman_Energy_Repsol_Market_Release_tcm 13-58475.pdf $>$ accessed 7 August 2019.

Repsol, 'Iraq' < https://www.repsol.com/en/repsol-worldwide/asia/iraq/index.cshtml> accessed 9 July 2019.

Rigzone, Gulf Keystone Signs PSC with KRG for Stake in Shaikan Block'

<https://www.rigzone.com/news/oil_gas/a/52564/gulf_keystone_signs_psc_with_krg_for_stake_in_shaikan_bl ock/> accessed 4 August 2019.

Rosneft, 'Operating Results for Q3 and 9M 2017'<https://www.rosneft.com/press/releases/item/188603/> accessed 12 August 2019.

Rosneft, 'Q1 2017 Operating Results' <https://www.rosneft.com/press/releases/item/186405/> accessed 12 August 2019.

ShaMaran Petroleum Crop, 'Atrush Project' < https://www.shamaranpetroleum.com/operations/atrush-project/> accessed 6 August 2019.

ShaMaran Petroleum Crop, 'Oil Exploration and Development in Iraqi - Kurdistan' <https://www.shamaranpetroleum.com> accessed 6 August 2019.

ShaMaran Petroleum Crop, 'ShaMaran to Acquire Additional 7.5\% Stake in Atrush' <https://www.shamaranpetroleum.com/news/shamaran-to-acquire-additional-7-5-stake-in-atrus-122702/> accessed 6 August 2019.

TOTAL, 'TOTAL in Iraq' <https://www.total.com/en/iraq-> accessed 7 August 2019.

Western Zagros, 'Garmian Block (Western Zagros 40\% Working Interest' <http://www.westernzagros.com/ouroperations/garmian-block/> accessed 4 August 2019.

Western Zagros, 'Kurdamir Block (WesternZagros 40\% Working Interest' <http://www.westernzagros.com/ouroperations/kurdamir-block/> accessed 4 August 2019.

\section{Journal Articles:}

Abbas Zadeh, Y and Kirmanji, S 'The Para-Diplomacy of the Kurdistan Region in Iraq and the Kurdistan Statehood Enterprise' (2017) 71(4) Middle East Journal 557-606.

Gunter, M M, 'Iraqi Kurdistan's Two Contrasting Economic Images' (2012)6(1) International Journal of Contemporary Iraqi Studies 89-95.

Salih, R S and Salih, M S, 'Procedures of Disputes Resolution Between the Kurdistan Regional Government and International Oil and Gas Companies: Dana Gas and its alliancesas a Case Study (in Kurdish)' (2019)1 Proceeding of The 4th International Legal Issues Conference/ Ishik (Tishk) University 30/4/2019,13-34.

Tas, D, 'Petroleum Development in the Kurdistan Region of Iraq: A Struggle Over Competency' (2011) 215 International Energy Law Review 1-19.

\section{Electronic Resources:}

Abdullah, D, 'ExxonMobil Pulled Out of Kurdistan: Because of Iranian Influence' < https://www.iraqbusinessnews.com/2017/01/05/exxonmobil-pulled-out-of-kurdistan-because-of-iranian-influence/>accessed 8 August 2019.

Blanchard, C M, 'Iraq: Oil and Gas Legislation, Revenue Sharing, and U.S. Policy' CRS Report for Congress, <http://www.fas.org/sgp/crs/mideast/RL34064.pdf> accessed 13 June 2019.

BOE Report, 'Talisman Energy Inc. and Related Canadian Partnerships Announce Name Changes' $<$ https://boereport.com/2016/01/04/talisman-energy-inc-and-related-canadian-partnerships-announce-namechanges/> accessed 7 August 2019.

Bousso, R and Zhdannikov, D, ' Chevron Drills Oil Well in Iraqi Kurdistan Area after Two-Year Gap' <https://www.reuters.com/article/us-chevron-exploration/chevron-drills-oil-well-in-iraqi-kurdish-area-aftertwo-year-gap-sources-idUSKCN1BV1UG> 6 August 2019.

Iraq Databank, Summary of Kurdistan Region Exploration Block Activity, 2014 to 2016' <http://www.iraqdatabank.org/storage/app/uploads/public/59d/37a/b2c/59d37ab2cd013842088027.pdf?i=1> accessed 5 August 2019.

Iraqi Oil Report, 'Exxon Cuts Kurdistan Portfolio by Half' < https://www.iraqoilreport.com/news/exxon-cuts-kurdistanportfolio-half-20566/?utm_source=IOR\%20Newsletter> accessed 8 August 2019. 
Ji-hye, J, 'Korean Lawmaker Lowers Kurdistan Oil Prospects' < https://ekurd.net/korean-lawmaker-lowers-kurdistanoil-prospects-2015-03-19> accessed 8 August 2019.

Katona, V 'The Energy Giant Taking Over Kurdistan' < https://oilprice.com/Energy/Energy-General/The-EnergyGiant-Taking-Over-Kurdistan.html> accessed 12 August 2019.

Lee, J, 'KNOC drops Sangaw South Project' <https://www.iraq-businessnews.com/2016/09/05/knoc-drops-sangawsouth-project/> accessed 5 August 2019.

Lee, J, 'KNOC drops Sangaw South Project' <https://www.iraq-businessnews.com/2016/09/05/knoc-drops-sangawsouth-project/> accessed 5 August 2019.

Mills, R, A Rocky Roud: Kurdish Oil \& Independence, Paper Number: IEI190218 (Iraqi Energy Institute, Baghdad 2018) p.48 <https://iraqenergy.org/product/a-rocky-road-kurdish-oil-and-independence-report/>accessed 4 August 2019.

Mills, R, Under the Mountains: Kurdish Oil and Regional Politics, OIES Paper: WPM 63 (Oxford Institute for Energy Studies, Oxford 2016) <https://www.oxfordenergy.org/wpcms/wp-content/uploads/2016/02/Kurdish-Oil-andRegional-Politics-WPM-63.pdf>accessed 4 August 2019.

Min-hee, 'KNOC Pulls Out of Iraq's Sangaw Soth Oil Field Project' <http://www.businesskorea.co.kr/news/articleView.html?idxno=15631> accessed 5 August 2019.

Min-hee, J, 'KNOC Pulls Out of Iraq's Sangaw Soth Oil Field Project' $<$ http://www.businesskorea.co.kr/news/articleView.html?idxno=15631> accessed 5 August 2019;

Osgood, P, 'OMV to Relinquish two blocks in Iraqi Kurdidstan' < https://www.iraqoilreport.com/news/omv-torelinquish-two-blocks-in-iraqi-kurdistan-9113/> accessed 6 August 2019.

Proactive Investors: United Kingdom, 'Kurdistan Region of Iraq - Land of Opportunity' <https://www.proactiveinvestors.co.uk/companies/news/258438/kurdistan-region-of-iraq-land-of-opportunity10165.html> accessed 12 June 2019.

Rebuilding Iraq, 'TAQA and ShaMaran Petroleum Acquire Atrush Stake from Marathon Oil' $<$ https://rebuildingiraq.net/news/view/102384-TAQA-and-ShaMaran-Petroleum-Acquire-Atrush-Stake-fromMarathon-Oil> accessed 6 August 2019

Reuters, Iraqi Kurdistan Gives Turkish Company Six Oil Exploration Blocks' $<$ https://www.reuters.com/article/turkeykurdistan-oil/iraqi-kurdistan-gives-turkish-company-six-oil-exploration-blocks-idUSL5N0EU44120130618> accessed 8 August 2019.

Shadow Governance Intel, 'Turkey Expands Influence in Kurdish Energy Sector' < https://oilprice.com/Energy/OilPrices/Turkey-Expands-Influence-In-Kurdish-Energy-Sector.html\#> accessed 8 August 2019.

The Oil \& Gas Year, 'ExxonMobil Exits Kurdistan Region Blocks' <https://www.theoilandgasyear.com/news/exxonmobil-exits-kurdistan-region-blocks/> accessed 8 August 2019.

Upstream Online, 'ExxonMobil Leaves blocks' < https://www.upstreamonline.com/hardcopy/1197633/exxonmobilleaves-blocks> accessed 8 August 2019.

Table of Statutes:

The Oil and Gas Law of the Kurdistan Region- Iraq No. (22) of 2007. 